\title{
Hematopoietic stem cells and retroviral infection
}

\author{
Prabal Banerjee ${ }^{1,2 \dagger}$, Lindsey Crawford ${ }^{1 \dagger}$, Elizabeth Samuelson ${ }^{1}$, Gerold Feuer ${ }^{1,2^{*}}$
}

\begin{abstract}
Retroviral induced malignancies serve as ideal models to help us better understand the molecular mechanisms associated with the initiation and progression of leukemogenesis. Numerous retroviruses including AEV, FLV, MMuLV and HTLV-1 have the ability to infect hematopoietic stem and progenitor cells, resulting in the deregulation of normal hematopoiesis and the development of leukemia/lymphoma. Research over the last few decades has elucidated similarities between retroviral-induced leukemogenesis, initiated by deregulation of innate hematopoietic stem cell traits, and the cancer stem cell hypothesis. Ongoing research in some of these models may provide a better understanding of the processes of normal hematopoiesis and cancer stem cells. Research on retroviral induced leukemias and lymphomas may identify the molecular events which trigger the initial cellular transformation and subsequent maintenance of hematologic malignancies, including the generation of cancer stem cells. This review focuses on the role of retroviral infection in hematopoietic stem cells and the initiation, maintenance and progression of hematological malignancies.
\end{abstract}

\section{Introduction}

Hematopoiesis is a highly regulated and hierarchical process wherein hematopoietic stem cells (HSCs) differentiate into mature hematopoietic cells [1]. It is a process controlled by complex interactions between numerous genetic processes in blood cells and their environment. The fundamental processes of self-renewal and quiescence, proliferation and differentiation, and apoptosis are governed by these interactions within both hematopoietic stem cells and mature blood cell lineages. Under normal physiologic conditions, hematopoietic homeostasis is maintained by a delicate balance between processes such as self-renewal, proliferation and differentiation versus apoptosis or cell-cycle arrest in hematopoietic progenitor/hematopoietic stem cells (HP/HSCs). Under stress conditions, such as bleeding or infection, fewer HP/HSCs undergo apoptosis while increased levels of cytokines and growth factors enhance proliferation and differentiation. In a normally functioning hematopoietic system, the kinetics of hematopoiesis return to baseline levels when the stress conditions end. Deregulation of the signaling pathways that control the various hematopoietic processes leads to abnormal

\footnotetext{
* Correspondence: feuerg@upstate.edu

† Contributed equally

'Department of Microbiology and Immunology, SUNY Upstate Medical University, Syracuse, NY, 13210, USA
}

hematopoiesis and is associated with the development of cancer, including leukemia (reviewed in [2]).

Although not fully characterized, deregulation of normal hematopoietic signaling pathways in HP/HSCs following viral infection has previously been documented [3-5]. Previous studies demonstrated productive infection of HP/HSCs by retroviruses and suggested that retroviral mediated leukemogenesis shares similarities with the development of other types of cancer, including the putative existence of cancer stem cells (CSCs) [6,7]. Here we discuss the evidence demonstrating that retroviruses can infect $\mathrm{HP} / \mathrm{HSCs}$, and we speculate on the ability of Human T-cell lymphotropic virus type 1 (HTLV-1) to generate an "infectious" leukemic/cancer stem cell (ILSC/ICSC).

\section{What Defines a HSC?}

HSCs are pluripotent stem cells that can generate all hemato-lymphoid cells. A cell must meet four basic functional requirements to be defined as a HSC: 1) the capability for self-renewal, 2) the capability to undergo apoptosis, 3) the maintenance of multilineage hematopoiesis, and 4) the mobilization out of the bone marrow into the circulating blood. The ability of HSCs to permanently reconstitute an irradiated recipient host is the most stringent test to evaluate if a population is a true HSC. Long-term transplantation experiments suggest a clonal diversity model of HSCs where the HSC 
compartment consists of a fixed number of different types of HSCs, each with an epigenetically preprogrammed fate. The HP/HSC population is typically defined by surface expression of CD34 and represents a heterogeneous cell population encompassing stem cells, early pluripotent progenitor cells, multipotent progenitor cells, and uncommitted differentiating cells [8]. HSCs have the potential to proliferate indefinitely and can differentiate into mature hematopoietic lineage specific cells.

In adults, HSCs are maintained within the bone marrow and differentiate to produce the requisite number of highly specialized cells of the hematopoietic system. HSCs differentiate into two distinctive types of hematopoietic progenitors: 1) a common lymphoid progenitor (CLP) population that generates B-cells, T-cells and NK cells, and 2) a common myeloid progenitor (CMP) population that generates granulocytes, neutrophils, eosinophils, macrophages and erythrocytes (Figure 1). Lineage commitment of these progenitors involves a complex process that can be induced in response to a variety of factors, including the modulation of hematopoietic-associated cytokines and transcription factors. These factors serve dual purposes both by maintaining pluripotency and by actively inducing lineage commitment and differentiation of HSCs [9-18]

\section{Leukemia Stem Cells/Cancer Stem Cells (LSC/CSC)}

The cancer stem cell hypothesis postulates that cancer can be initiated, sustained and maintained by a small number of malignant cells that have HSC-like properties including self-renewal and pluripotency [19-21]. The hierarchical organization of leukemia was first proposed by Fialkow et al. in the 1970s, and it was later demonstrated that acute myeloid leukemia (AML) contains a diversity of cells of various lineages but of monoclonal origin [22]. It is now well established that HSCs are not only responsible for the generation of the normal hematopoietic system but can also initiate and sustain the development of leukemia, including AML $[2,7,23]$. This hematopoietic progenitor, termed a leukemic/cancer stem cell (LSC/CSC), is the result of an accumulation of mutations in normal HSCs that affect proliferation, apoptosis, self-renewal and differentiation [24]. One of the most well established models for this theory came from the seminal work of John Dick and colleagues that established cancer stem cells at the top of a hierarchical pyramid for the establishment of AML [25]. Many signaling pathways, such as the Wnt signaling pathway, that have been classically associated with solid cancers are now also associated with HSC development and disease [26,27]. CSCs have been unequivocally identified in AML and are also suspected to play a role in other leukemias, including chronic myelogenous leukemia (CML) and acute lymphoblastic leukemia (ALL) [28-30].

In order to be defined as a LSC/CSC, cells must have the ability to generate the variety of differentiated leukemic cells present in the original tumor and must demonstrate self-renewal. The classical experiment to define a cancer stem cell is its ability to reproduce the disease phenotype of the original malignancy in immunocompromised mice. LSC/CSC have the ability to recapitulate the original disease phenotype following transplantation into NOD/SCID mice as illustrated by the transplantation of $\mathrm{CD} 34^{+} \mathrm{CD} 38^{-} \mathrm{LSC} / \mathrm{CSC}$ obtained from AML patients $[25,31,32]$. Interestingly, the CD34 ${ }^{+} \mathrm{CD} 38^{-}$cell surface phenotype of LSC/CSC is shared by immature hematopoietic precursors including HSCs, raising the possibility that LSC/CSC arise from HSCs. Indeed, the transplantation of mature $\mathrm{CD} 34^{+} \mathrm{CD} 38^{+}$cells fails to recapitulate AML in NOD/SCID mice indicating that the HSC rather than the more mature $\mathrm{CD} 34^{+} \mathrm{CD} 38$ ${ }^{+}$progenitor cell, is the LSC/CSC. The identification and characterization of LSC/CSC is critical for designing specific therapies since LSC/CSCs are relatively resistant to traditional radiation and chemotherapy [33-35]. This theory provides an attractive model for leukemogenesis because the self-renewal of HSCs allows for multiple genetic mutations to occur within their long life span. For HSCs to become LSC/CSC, fewer genetic mutations may be required than in mature hematopoietic cells, which must also acquire self-renewal capacity [36].

\section{The Cancer Stem Cell Hypothesis}

There are currently three hypotheses that address the question of which target cell in cancer undergoes leukemic transformation (Figure 2) [34]. The first hypothesis proposes that multiple cell types within the stem and progenitor cell hierarchy are susceptible to transformation. Mutational events alter normal differentiation patterns and promote clonal expansion of leukemic cells from a specific differentiation state. The second hypothesis proposes that the mutations responsible for transformation and progression to leukemia occur in primitive multipotent stem cells and result in the development of a LSC/CSC. Thus, disease heterogeneity results from the ability of the LSC/CSC to differentiate and acquire specific phenotypic lineage markers [37]. The final hypothesis proposes that progression to acute leukemia may require a series of genetic events beginning with clonal expansion of a transformed LSC/CSC. This "two-hit" model of leukemogenesis suggests that there is a pre-leukemic stem cell that has undergone an initial transformation event, but has not yet acquired the additional mutations necessary to progress to leukemia [38]. 


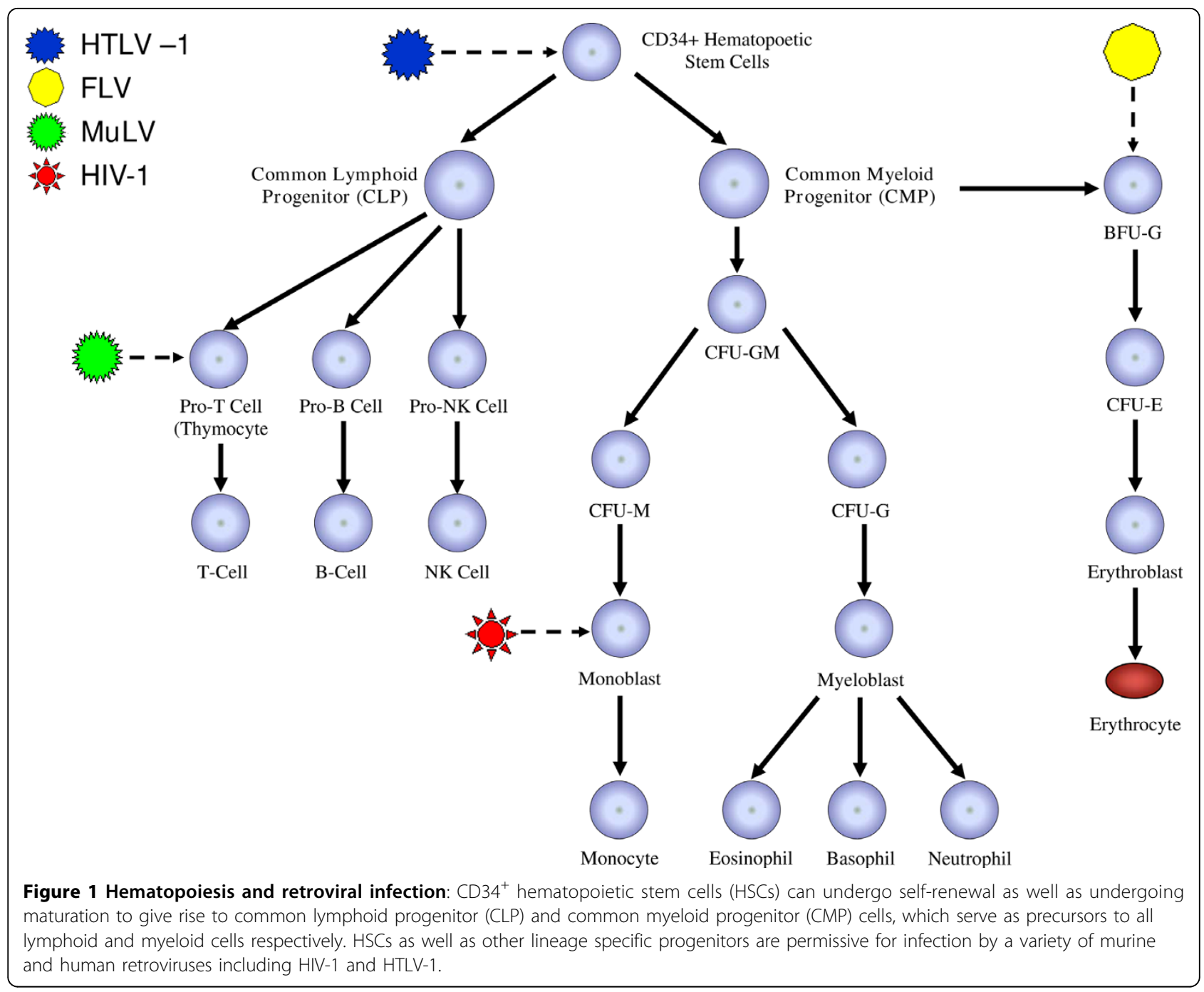

Deregulation of genes involved in normal HSC selfrenewal and differentiation in human cancer suggests an overlap in the regulatory pathways used by normal and malignant stem cells. Emerging evidence suggests that both normal and cancer stem cells share common developmental pathways. Since the signaling pathways that normally regulate HSC self-renewal and differentiation are also associated with tumorigenesis, it has been proposed that HSCs can be the target for transformation in certain types of cancer [20]. HSCs already have the inherent ability for self-renewal and persist for long periods of time in comparison to the high turnover rate of mature, differentiated cells. HSCs possess two distinctive properties that can be deregulated to initiate and sustain neoplastic malignancies, namely self-renewal and proliferation. Retroviral infection in HSCs may therefore result in the accumulation of mutations and in the modulation of key hematopoiesis-associated gene expression patterns. The alteration of normal hematopoietic signaling pathways, including those related to selfrenewal and differentiation, may lead to the generation of a LSC/CSC population. During normal hematopoiesis, the HSC undergoes self-renewal or enters a committed, lineage specific differentiation and maturation pathway. Once HSCs commit to a lineage specific pathway and become terminally differentiated, they lose the capacity to undergo self-renewal $[39,40]$. LSC/CSC however can undergo long-term proliferation without entering terminal differentiation resulting in the manifestation of hematological malignancies.

\section{Retroviral Infection and Hematopoiesis}

Recent evidence suggests that viral infection may have a profound influence on normal hematopoiesis [41]. Viral infection of HP/HSCs may adversely affect the levels of cytokines and transcription factors vital for proliferation and differentiation. Alternatively, viral infection may induce cytolysis, apoptosis and/or the destruction of 


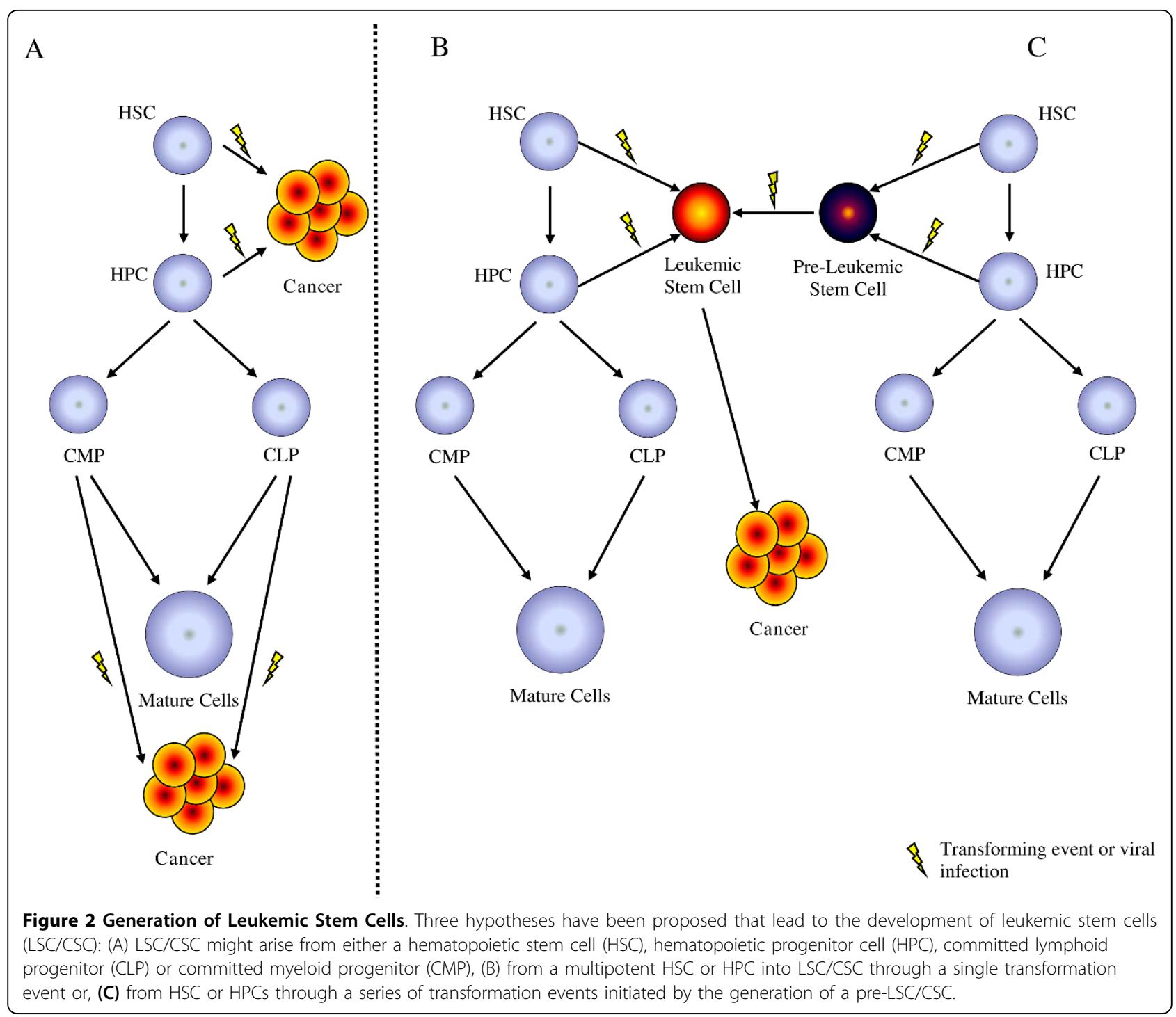

progenitor cells, resulting in perturbation of hematopoiesis. Additionally, infected HPCs may differentiate resulting in dissemination of pathogens into diverse anatomical sites and to an effective spread of infection.

$\mathrm{HP} / \mathrm{HSCs}$ can also serve as targets for cellular transformation by specific viruses partly because of their innate ability for self-renewal. CD $34^{+} \mathrm{HP} / \mathrm{HSCs}$ are susceptible to infection with a number of viruses including HIV-1, HTLV-1, Hepatitis C virus, JC virus, Parvovirus, Human Cytomegalovirus (HCMV), and the Human Herpesviruses (HHV): HHV -5, HHV -6 , HHV -7 , HHV -8 [3-5,42-52]. The concept that viruses can invade, infect and establish a latent infection in the bone marrow was first demonstrated in studies with HCMV. HCMV infects a variety of cell types, including hematopoietic and stromal cells of the bone marrow, endothelial cells, epithelial cells, fibroblasts, neuronal cells, and smooth muscle cells [3,53-57]. The bone marrow is a site of HCMV latency [5,58], but the primary cellular reservoir harboring latent virus within the bone marrow is controversial. Latent viral genomes are detected in $\mathrm{CD} 14^{+}$ monocytes and $\mathrm{CD}^{2} 3^{+}$myeloid precursor cells $[59,60]$. However HCMV can also infect CD34 $4^{+}$hematopoietic progenitor populations, and viral DNA sequences can be detected in $\mathrm{CD} 34^{+}$cells from healthy seropositive individuals $[45,46,58,61]$, suggesting that a primitive cell population serves as a renewable primary cellular reservoir for latent HCMV. The finding that HCMV DNA sequences are present in $\mathrm{CD} 34^{+}$cells of seropositive individuals is consistent with the hypothesis that HCMV resides in a HPC which subsequently gives rise to multiple blood cell lineages. Recently, it has also been proposed that other viruses such as HTLV-1 and Kaposi's Sarcoma Herpesvirus (KSHV) can also infect CD34 ${ }^{+}$ 
$\mathrm{HP} / \mathrm{HSCs}$ and establish latent infection within the BM resident cells [52,62].

Apart from the establishment of latent infection within the bone marrow (BM), suppression of hematopoiesis has been documented to occur following infection of HPCs with HCMV, HHV-5, HHV-6, HIV-1, and measles virus either as a result of direct infection of HPCs or by indirect mechanisms such as disruption of the cytokine milieu within the stem cell niche following infection of bone marrow stromal cells. Our laboratory has reported that HTLV-1 and KSHV infection of CD34 ${ }^{+} \mathrm{HP} / \mathrm{HSCs}$ suppresses hematopoiesis in vitro and that viral infection can be disseminated into mature lymphoid cell lineages in vivo when monitored in humanized SCID mice (HU-SCID) [52,63,64]. HTLV-1 and KSHV are both associated with hematological malignancies and it is plausible that CSCs can be generated following infection of $\mathrm{HP} / \mathrm{HSCs}$ with these viruses.

Multiple retroviruses establish latent infections in $\mathrm{HP} /$ HSCs resulting in perturbation of hematopoiesis and induction of viral pathogenesis [65-69]. Retroviral infections of HSCs can have adverse effects including induction of cell-cycle arrest and increased susceptibility to apoptosis, both would manifest in the suppression of hematopoiesis. Additionally, mutations and transcriptional deregulation of specific hematopoiesis-associated genes can skew normal hematopoiesis toward specific lineages and have been demonstrated to occur following infection of HP/HSCs with HIV-1, HTLV-1 and Friend Leukemia virus (FLV) [64,70,71].

Hematopoiesis occurs in the bone marrow microenvironment, a complex system comprised of many cell types including stromal cells that produce cytokines, growth factors and adhesion molecules vital for the maintenance, differentiation and maturation of $\mathrm{HP} / \mathrm{HSCs}$ $[9,11]$. Apart from infection of HSCs, retroviruses such as HIV-1 and Moloney Murine leukemia virus (MMuLV) have been shown to infect bone marrow stromal cells, compromising their ability to support hematopoiesis and resulting in multilineage hematopoietic failure $[72,73]$.

\section{Retroviruses and Leukemogenesis: The "two-hit" Hypothesis}

Studies of retroviral induced leukemia have proven very useful in understanding the multi-step processes associated with leukemogenesis. Moreover, these models have broadened our understanding of hematopoiesis and hematopoietic stem cell biology. Retroviral infection models such as FLV and M-MuLV, which induce leukemic states in mice, have emerged as powerful tools to study the molecular mechanisms associated with leukemogenesis and the generation of LSC/CSCs [74-78]. The emerging concept from these murine models is that acute leukemia arises from cooperation between two distinctive mutagenic events; one interfering with differentiation and another conferring a proliferative advantage to HP/HSCs (Figure 2C) [79,80]. Studies from Avian Erythroblastosis virus (AEV), FLV and M-MuLVinduced leukemia/lymphoma models demonstrate that leukemia/lymphoma development depends on: (1) a mutation that impairs differentiation and blocks maturation, (2) a mutation that promotes autonomous cell growth, and (3) that neither mutational event is able to induce acute leukemia by itself $[68,81]$. Thus, these models provide direct evidence for the "two-hit model" of leukemogenesis as has been proposed for some LSC/ CSC induced hematological malignancies, including AML [79]. This concept is perhaps best illustrated by AEV infection in birds, FLV and MuLV infection in mice and in HTLV-1 infection in humans (Figure 3).

During AEV infection, the oncogenic tyrosine kinase $\mathrm{v}-E r b-b$, together with the aberrant nuclear transcription factor $v-E r b-A$ are transduced. The mutated thyroid hormone receptor $\alpha, v-E r b-A$, becomes unresponsive to the ligand and actively recruits tyrosine kinases. These kinases, such as stem-cell factor activated c-kit, cause arrest of erythroid differentiation at the BFU-E/CFU-E stage. Additionally, $v-E r b-b$ encodes a mutated epidermal growth factor receptor that induces extensive erythroblast self-renewal $[69,82]$. These two virally-induced events promote the abnormal proliferation of erythroid progenitors and lead to the development of leukemia.

Another relevant leukemogenesis model induced by retroviral infection of HPCs is acute erythroleukemia caused by the infection of mice with FLV [83-85]. FLV has two distinct viral components, a replication-competent Friend Murine Leukemia virus (F-MuLV) and a replication defective pathogenic component known as the Friend Spleen Focus Forming virus (F-SFFV) [85-87]. The pathogenic component of FLV (F-SFFV) can infect a variety of hematopoietic cells, though early erythroid progenitors are the primary target for infection $[86,88]$. F-SFFV can alter the normal growth and differentiation profile of erythroid progenitor cells leading to leukemogenesis. The induction of multistage erythroleukemia by FLV is also a two stage process: a pre-leukemic stage known as "erythroid hyperplasia" and a leukemic phase referred to as "erythroid cell transformation" (Figure 3B). The pre-leukemic stage is characterized by the infection and random integration of F-SFFV virus into erythroid precursor cells, forming an infected stem cell population, followed by the expression of the viral envelope glycoprotein gp55 on the cell surface. gp55 subsequently binds to the cellular receptor of erythropoietin (Epo-R) and interacts with the sf-Stk tyrosine kinase signaling pathway leading to a constitutive activation signal for the proliferation of undifferentiated 


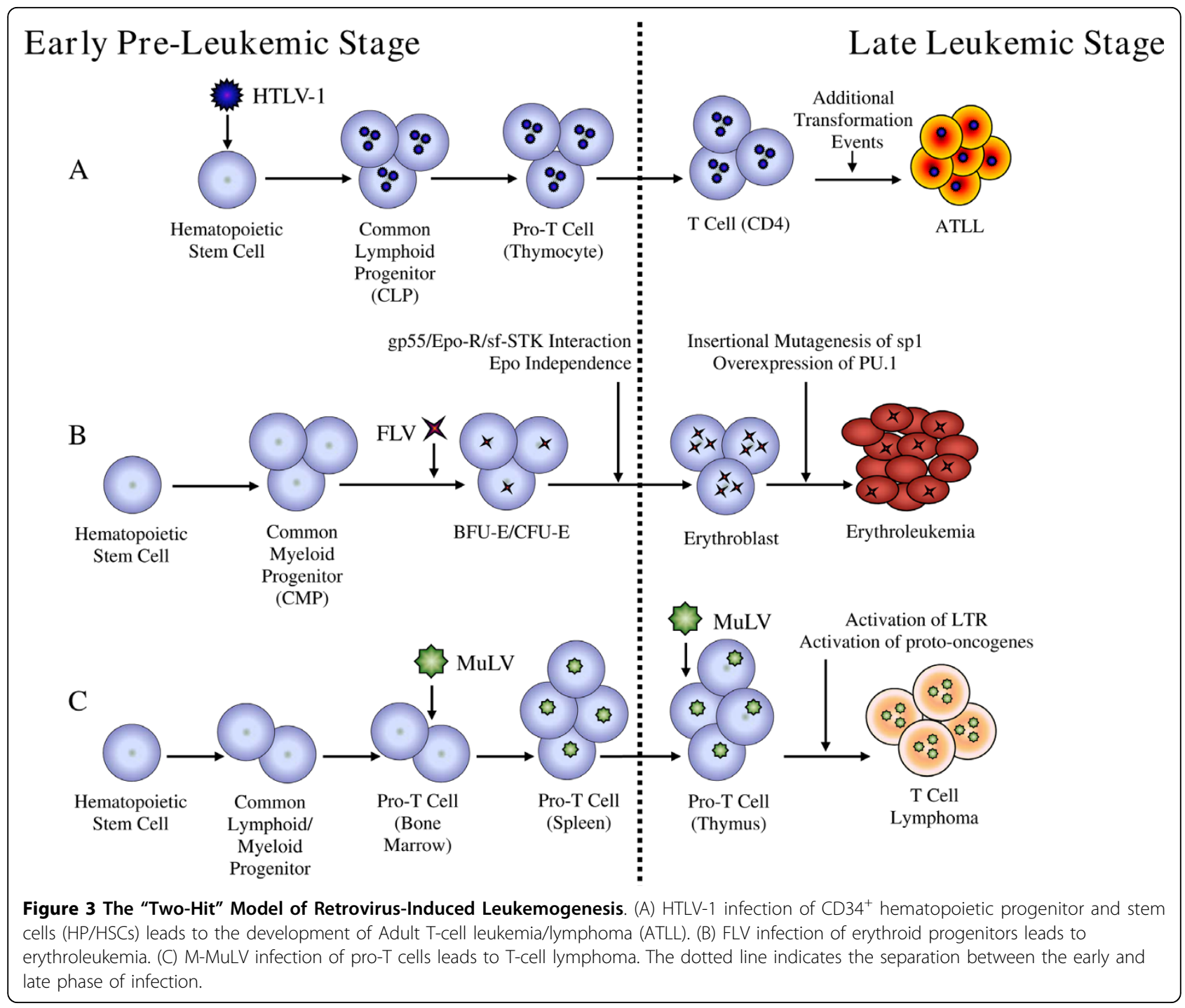

erythroid progenitor cells independent of erythropoietin $[83,89,90]$. Within the proliferating erythroid progenitor cell population are infected cells with randomly integrated virus in the $s p-1$ locus, which leads to the activation and overexpression of PU.1. Originally isolated by Moreau-Gachelin and co-workers as a gene targeted for recurrent insertions of SFFV, PU.1 has subsequently been shown to be involved in terminal myeloid differentiation, B and T-cell development, as well as maintenance of normal erythropoiesis and HSC development $[91,92]$. The over-expression of PU.1 in erythroid precursor cells as a result of SFFV integration leads to a block in erythroid differentiation and, in conjunction with the inactivation of p53, clonal expansion of these leukemic cells in susceptible mice $[71,91]$. Thus FLVmediated erythroleukemia is associated with two distinctive phases, "the pre-leukemic phase" mediated by gp 55 binding to Epo-R and the "leukemic phase" mediated by
SFFV integration and the subsequent over-expression of PU.1. This demonstrates that both AEV and FLV infection follow the two-hit model of the cancer stem cell hypothesis.

M-MuLV is a non-acute retrovirus that typically induces a T-cell lymphoma after a latency period of 3-6 months [67]. The tumor cells typically have the phenotype of immature $\mathrm{T}$-cells $\left(\mathrm{CD} 4^{-} / \mathrm{CD}^{-}\right.$or $\left.\mathrm{CD} 4^{+} / \mathrm{CD} 8^{+}\right)$ although some tumors show a more mature surface phenotype $\left(\mathrm{CD}^{+} / \mathrm{CD}^{-}\right.$or $\left.\mathrm{CD}^{-} / \mathrm{CD}^{+}\right)[72,93]$. This led to the hypothesis that the virus might originally infect an immature T-cell or a HPC to form a ICSC/ILSC which then continues to differentiate post-infection, initially in the bone marrow and then in the thymus $[67,94]$. Because T-lymphocytes develop in the thymus from bone marrow-derived immature precursors (prothymocytes), it has been proposed by several investigators that a bone marrow-thymus axis plays an important 
role in the development of T-cell lymphoma by $\mathrm{M}$ MuLV [93,95-97]. Although the identity of the initial target cell for M-MuLV infection is still unknown, a two-stage leukemogenesis model for the development of $\mathrm{M}-\mathrm{MuLV}$-induced leukemia has been proposed [67]. In this model the animal is infected with MuLV on two separate occasions; the first infection occurs in the bone marrow at the pre-leukemic (early) phase which leads to hyperplasia and migration of infected lymphoid progenitors into the thymus where a subsequent infection leads to insertional activation of proto-oncogenes and outgrowth of the tumor resulting in the leukemic (late) phase of infection (Figure 3C). Early infection of the bone marrow is thought to be essential for establishment of the pre-leukemic state and for development of spleen hyperplasia. The late phase splenic hyperplasia is the result of a compensatory hematopoiesis due to diminished normal hematopoiesis in the bone marrow resulting from the establishment of the preleukemic phase and plays an integral role in the establishment of malignancy [98-100].

Bovine leukemia virus (BLV) is a deltaretrovirus which causes leukemia/lymphoma in cattle [101] (reviewed by [102,103]) and has been used as a model of HTLV-1 infection and disease. While B-cells are the primary target of BLV infection in contrast to the $\mathrm{T}$ cell tropism displayed by HTLV-1, BLV-infected B lymphocytes are similarly arrested in $G_{0} / G_{1}$ and protected from apoptosis similar to properties demonstrated following HTLV-1 infection HP/HSCs [64,104]. It has been suggested that $\mathrm{CD}^{+} \mathrm{B}$-cell progenitors are more susceptible to BLV infection [105] and that there is a relationship between the $\mathrm{B}$-cell phenotype and BLV tropism [106]. More recently, the existence of a pre-malignant clone has been proposed. This infected progenitor is detectable early after viral infection and could contribute to both genetic instability and clonal expansion, both characteristics of cancer cells [107]. It can therefore be speculated that the infection of progenitor populations by $\mathrm{BLV}$ may result in the establishment of an ILSC/ICSC and subsequent development of leukemia.

Much of the current knowledge about leukemic mechanisms originates with studies on AML. AML is characterized by the uncontrolled self-renewal of hematopoietic progenitors that fail to differentiate normally. Induction of AML is associated with a variety of mutations that can be broadly classified into two distinctive categories; mutations in genes encoding transcription factors involved with hematopoietic regulation and mutations in genes encoding proteins linked to survival and proliferation signaling pathways [74-78,108,109]. Studies in mice have shown that neither type of mutation alone is sufficient for the induction of AML and that cooperative mutagenic events are required for disease initiation $[69,79]$. The leukemogenesis models of AEV, FLV and MuLV validate this concept and underline the importance of these models for the study of down-stream molecular events associated with these mutagenic events. The emergence of LSC/CSC as a result of these oncogenic events would explain the complexity associated with hematological malignancy development such as AML and CML in humans.

\section{Human T-cell Leukemia Virus Type-1 (HTLV-1) and Adult T-cell Leukemia/Lymphoma (ATLL)}

Human T-cell leukemia/lymphoma virus type-1 (HTLV-1) is the causative agent of Adult T-cell Leukemia/Lymphoma (ATLL), an aggressive CD4. leukemia/ lymphoma [110]. ATLL is a rare T-cell malignancy characterized by hypercalcemia, hepatomegaly, splenomegaly, lymphadenopathy, the presence of a monoclonal expansion of malignant $\mathrm{CD} 4{ }^{+} \mathrm{CD} 25^{+} \mathrm{T}$-cells that evolve from a polyclonal population of HTLV-1 infected $\mathrm{CD}^{+} \mathrm{T}$-cells, and infiltration of lymphocytes into the skin and liver. HTLV-1 causes ATLL in a small percentage of infected individuals after a prolonged latency period of up to 20-40 years [111]. Although HTLV-1 can replicate by reverse transcription during the initial phase of infection, the integrated provirus is effectively replicated during proliferation of infected cells [112]. Typically, HTLV-1 infected cells can persist for decades in patients, and the infected cell population transits from a polyclonal phase into a monoclonal expansion during development and progression to ATLL.

There are four ATLL subtypes; acute, lymphomatous, chronic, and smoldering. The first two subtypes are associated with a rapidly progressing clinical course with a mean survival time of 5-6 months. Smoldering and chronic ATLL have a more indolent course and may represent transitional states towards acute ATLL. Clinical features of ATLL include leukemic cells with multi-lobulated nuclei called 'flower cells' which infiltrate into various tissues including the skin and the liver, abnormally high blood calcium levels, and concurrent opportunistic infections in patients [113,114].

Although considerable progress has been made in understanding ATLL biology, the exact sequence of events occurring during the initial stages of malignancy, including the types of cells infected with HTLV-1, remain unclear. The primary target cells for HTLV-1 infection may not only influence HTLV-1 pathogenesis, but the sequestration of these cells in anatomical sites such as the bone marrow may also allow the virus to effectively evade the primary immune response against infection. 


\section{The Role of HSCs in HTLV-1 Infection and Pathogenesis}

It has been previously reported by our laboratory and other investigators that HTLV-1 can infect human HP/ HSCs [65,115]. It has been hypothesized that HTLV-1 can specifically induce a latent infection in $\mathrm{CD}^{+} 4^{+} \mathrm{HP} /$ HSCs and can initiate preleukemic events in these progenitor cells [62]. These cells could potentially provide a durable reservoir for latent virus in infected individuals. It has been speculated that HTLV-1 infection of CD34 ${ }^{+}$ HPCs may result in the generation of an ILSC/ICSC and may also induce perturbation of normal hematopoiesis, ultimately resulting in the outgrowth of malignant clones and the development of ATLL.

The development of ATLL correlates with neonatal or perinatal transmission of HTLV-1. HTLV-1 carries no cellular proto-oncogenes, and the oncogenic potential of the virus is linked to Tax1, a $40 \mathrm{kDa}$ protein that functions as a trans-activator of viral gene expression and as a key component of HTLV-1-mediated transformation $[116,117]$. Tax1 is a relatively promiscuous transactivator of both viral and cellular gene transcription and has been closely linked to the initiation of leukemogenesis. Apart from regulating viral gene expression through the 5 ' long terminal repeat (LTR), Tax1 can modulate the expression of a large variety of cellular genes and proteins including those encoding cytokines, apoptosis inhibitors, cell cycle regulators, transcription factors, and intracellular signaling molecules [116,118-120]. Tax1 usually induces cellular gene expression by the activation of transcription factors such as NF- $\kappa \mathrm{B}$ and cyclic AMP response element-binding protein/activating transcription factor (CREB/ATF) [121]. Tax1 has also been shown to transrepress transcription of certain cellular genes, including bax [122], human $\beta$-polymerase [119], cyclin A [123], lck [124], MyoD [125], INK4 [126], and p53 [127].

Transgenic mouse models of Tax1 expression have resulted in the generation of murine malignancies, including a mature $\mathrm{T}$-cell malignancy, underlying the critical role of Tax1 in the manifestation of T-cell leukemia $[128,129]$. Transgenic mice constructed to target expression of Tax1 to both immature and mature thymocytes using a Lck (Leukocyte-specific protein tyrosine kinase) promoter reproducibly develop immature and mature T-cell leukemia/lymphomas with immunological and pathological similarities to human ATLL $[128,129]$. In a recent study by Yamazaki et al., splenic lymphomatous cells were harvested and purified from Tax-transgenic mice using a combination of immunological and physiological markers for CSCs and were injected into NOD/SCID mice using a limiting-dilution assay [6]. Injection with as few as $1 \times 10^{2}$ CSCs was sufficient to recapitulate the original lymphoma and reestablish CSCs in recipient NOD/SCID mice implicating a role for LSC/CSC in the establishment of ATLL.

LSC/CSCs have the ability to self-renew, are sequestered in the bone marrow microenvironment and are relatively resistant to conventional chemotherapeutic treatment regimens. The recent focus and characterization of the role of LSC/CSC in the induction of AML has generated a paradigm for LSC/CSC-generated cancers and has resulted in a re-evaluation of therapeutic strategies for successful targeting and elimination of leukemic cells in patients [31]. Although the Tax-transgenic mouse model is not a complete representation of ATLL manifestation in humans, this finding is intriguing particularly since other investigators have suggested that HTLV-1 infection in the human bone marrow and in human HP/ HSCs specifically, may facilitate the early events initiating ATLL development [62]. Since a limited number of ATLL cases display phenotypes indicative of immature hematopoietic cells, HTLV-1 infection and transformation of $\mathrm{HP} / \mathrm{HSCs}$ in humans may result in the generation of virally-infected ATLL LSC/CSC [130]. Lymphoma cells and LSC/CSC from Tax-transgenic mice were also demonstrated to sequester in the osteoblastic and vascular niches of the bone marrow in transplanted NOD/ SCID mice. It is interesting to speculate that if ATLL arises from a LSC/CSC, then the sequestration of HTLV1 -infected HP/HSCs in the bone marrow microenvironment may be a contributing factor in the resistance of this leukemia to treatment with conventional chemotherapies. It remains to be determined if the recent results from the Tax-transgenic model are truly illustrative of the human disease. However, the Tax-transgenic murine model does provide several interesting clues into the mechanisms of HTLV-1 pathogenesis, and this may eventually group ATLL along with other hematological malignancies that have a LSC/CSC origin.

Recapitulating ATLL in 'humanized' SCID (HU-SCID) mice has been challenging, and previous attempts to directly infect mature human $\mathrm{T}$-cells in the human thymus-liver conjoint organ in HU-SCID mice with HTLV1 failed to induce a malignancy [65]. Recent data from our laboratory demonstrates that ex vivo infection of CD $34^{+} \mathrm{HP} / \mathrm{HSCs}$ with HTLV-1 reproducibly and consistently results in development of a $\mathrm{CD} 4^{+} \mathrm{T}$-cell lymphoma in HU-SCID mice [131]. Clearly, HTLV-1 infection of $\mathrm{HP} / \mathrm{HSCs}$ plays a pivotal role in the initiation and accelerated progression of malignancy during the course of HTLV-1 pathogenesis.

\section{HTLV-1 Infected CD34 ${ }^{+}$HP/HSCs: Notch, PU.1 and micro-RNA Deregulation}

Manifestation of ATLL in patients generally occurs decades after infection, suggesting that HTLV-1 latently 
infects bone marrow stem cells that are sequestered from immunological surveillance. It is conceivable that the initiation of leukemogenesis in HSCs involves the generation of a CSC/LSC that will eventually manifest into the monoclonal ATLL malignancy. Several pathways that regulate HSC self-renewal are also associated with human cancers, including hematopoietic malignancies such as T-cell leukemia [132] and T-ALL [133,134]. It has previously been shown that disruption of normal HSC self-renewal signaling pathways can induce hematopoietic neoplasms $[132,135]$. Two main reasons suggest that HSCs can serve as target cells for virallyinduced leukemia/lymphoma. First, stem cells have constitutively activated self-renewal pathways, requiring maintenance of activation in contrast to the de novo activation required in a more differentiated cell. Second, self-renewal provides a persistent target for repeated viral infection and/or continual replication of integrated proviral DNA. HTLV-1 infection of CD34 ${ }^{+} \mathrm{HP} / \mathrm{HSCs}$ deregulates normal HSC self-renewal pathways through a variety of potential mechanisms suggesting that HTLV-1 infection may generate ILSC/ICSC.

The Notch signaling pathway regulates self-renewal and differentiation of HSCs and has been implicated as a key regulator of human $\mathrm{T}$ and B-cell derived lymphomas $[135,136]$. Studies using adult bone marrow transplantation into NOD/SCID mice demonstrate that inactivation of Notch1 arrests T-cell development at the earliest precursor stage [134] and promotes B-cell development in the thymus [137]. The modulation of Notch levels in LSC/CSC derived from Tax-transgenic mice suggests that Notch may contribute in the development of ATLL similar to its role in other T-cell malignancies such as T-ALL $[133,134]$.

The $s p 1$ gene encodes for the transcription factor $P U .1$, which is a member of the ets family of transcription factors, is expressed at various levels in all hematopoietic cells. PU.1 expression has been shown to play an important role in the regulation of hematopoiesis $[138,139]$. Specifically, expression of PU.1 is tightly controlled in HSCs and regulates the fate of cells differentiating into lymphocyte, macrophage or granulocyte lineages [140,141]. Deregulation of PU.1 expression has been linked to the development of hematopoietic malignancies including the transformation of myeloid cells [92]. During hematopoiesis, PU.1 is required for hematopoietic development along both the lymphoid and myeloid lineages, but is down-regulated during erythropoiesis. In AML patients, mutations in Flt3 decrease PU.1 expression and block differentiation [141] while mutations in PU.1 impair development within both myeloid and lymphoid lineages [142]. Knockout mouse studies have shown that perturbation of PU.1 expression results not only in the loss of $\mathrm{B}$-cells and macrophage development, but also delays T lymphopoiesis [143,144]. Additionally, PU.1 supports the self-renewal of HSCs by regulating the multilineage commitment of multipotent progenitors, thereby maintaining a pool of pluripotent HSCs within the bone marrow $[145,146]$.

Notably the reduction in PU.1 expression in bone marrow derived CD $34^{+} \mathrm{HP} / \mathrm{HSCs}$ has been shown to induce an intermediate stage of poorly differentiated pre-leukemic cells which, with the accumulation of additional genetic mutations, results in an aggressive form of AML [147]. The HTLV-I accessory protein p30 has also been shown to interact with the ets domain of PU.1 resulting in impairment of the DNA binding activity of PU.1 and subsequent inhibition of PU.1-dependent transcription [148]. HTLV-1 p30-mediated alteration of $P U .1$ expression may be a contributing factor in the deregulation of hematopoiesis due to HTLV-1 infection of HSCs and may contribute to the establishment of ILSC/ICSC.

Bmi-1 (B-lymphoma Mo-MuLV insertion region), which belongs to the polycomb group of epigenetic chromatin modifiers, was originally identified as an oncogene [149]. Bmi-1 is required for the maintenance of HSC self-renewal in mice and is also involved in regulation of genes controlling cell proliferation, survival and differentiation of HSCs [149-152]. Deficiency of $\mathrm{Bmi}-1$ results in a progressive loss of HSCs and in defects in the stem cell compartment of the nervous system [153]. Bmi-1 expression is elevated in HP/HSCs in contrast to differentiated hematopoietic cells, and both self-renewal as well as the in vivo repopulation potential of HSCs is dependent on Bmi-1 [152,154-156]. It has been reported that Bmi-1 is required for the activation and survival of pre-T-cells and during transition from DN to DP T-cells [157]. Bmi-1 is required for the proliferation of LSC/CSCs, and the deregulation of Bmi-1 is linked to human cancers $[155,158]$. Notably LSC/CSCs from Tax1-transgenic mice show a robust down-regulation of Bmi-1, providing a mechanistic link between HTLV-1 infection and deregulation of hematopoiesis.

Micro-RNAs (miRNAs) are a class of non-coding RNAs, 20-25 nucleotides long, that play an important role in both normal and malignant hematopoiesis, including self-renewal, differentiation and lineage specificity of HPCs [159-163] (reviewed in [164]). Loss of miRNAs has also been reported in a variety of cancers indicating that alteration of miRNA levels might play a critical role in tumorigenesis [165-167]. miR-150 is preferentially expressed in the megakaryocytic lineage and has been recently shown to drive the differentiation of megakaryocyte-erythrocyte precursors toward megakaryocyte development at the expense of erythroid differentiation [168]. Over-expression of miR-221 and miR-222 interferes with the kit receptor and blocks engraftment 
of HSCs in humanized mice [169]. Over-expression of miRNA-181a has been linked to the development of AML and CLL $[170,171]$. These studies highlight the role of miRNA in regulating normal hematopoiesis and suggest that miRNA expression may modulate the manifestation of hematopoietic malignancies.

Retroviruses such as HIV-1 and HTLV-1 have been recently shown to target miRNAs for modulation of key cellular pathways including cell-cycle regulation and immune responses [172-174]. Specifically, miRNAs that are involved in the regulation of cell proliferation, apoptosis and immune responses are up-regulated in ATL cells $[175,176]$. Bellon et al. recently demonstrated that miRNAs involved in normal hematopoiesis and immune responses are also profoundly deregulated in ATLL cells indicating a possible link between modulation of cellular miRNA expression and deregulation of hematopoiesis by HTLV-1 [177]. Specifically, significant changes in the expression of miR-223 and miR-150 in ATLL patient samples were identified. miR-223 controls the terminal differentiation pathway of HSCs and is upregulated following differentiation into myeloid and lymphoid progenitors [162]. The differential expression of miR-150 regulates lineage decision between $\mathrm{T}$ and B-cells. Ectopic expression of miR-150 in lymphoid progenitors enhances T lymphopoiesis with respect to B lymphopoiesis [178]. The deregulation of cellular miRNAs might contribute to the transformation process resulting in the development of ATLL.

HTLV-1 infection in HP/HSC could result in aberrant miRNA expression ultimately predisposing HSC development toward T lymphopoiesis. Since expression of these miRNAs (223 and 150) are restricted to HP/HSCs, CLPs and CMPs, patient derived primary ATLL cells may originated from an infected HPC population in contrast to in vitro-established HTLV-1 infected CD4 ${ }^{+}$ $\mathrm{T}$ cell lines. This supports the hypothesis that ATLL cells are derived from HTLV-1 infected CD $34^{+} \mathrm{HP} /$ HSCs rather than virally transformed mature T-cells $[64,128,129]$. Upon differentiation of an HTLV-1 infected CD34 ${ }^{+}$HPC, the alteration of miRNA levels may favor $\mathrm{T}$-cell differentiation, as recently demonstrated by the exclusive development of $\mathrm{CD} 4^{+}$mature T-cell lymphomas in HU-SCID mice reconstituted with CD $34^{+}$HPCs infected ex vivo with HTLV-1[131].

\section{Tax1 and Cell Cycle Regulation in HP/HSCs}

HTLV-1 Tax 1 has been shown to induce $G_{0} / G_{1}$ cell cycle arrest leading to quiescence in both cultured mammalian cell lines and primary human CD $34^{+}$HPCs $[116,179,180]$. Likewise, the expression of Tax1 in Saccharomyces cerevisiae leads to growth arrest and loss of cell viability [181,182]. Intriguingly, in addition to increasing the levels of cyclins and CDKs, Tax1 also increases the levels of CDK inhibitors $\mathrm{p} 16^{\mathrm{Ink} 4}, \mathrm{p} 21^{\mathrm{cip} 1 /}$ waf1 (p21) and p27 ${ }^{\text {kip }}$ (p27) in infected cells $[63,64,179,183,184]$. Over-expression of p21 inhibits two critical checkpoints in the mammalian cell cycle, namely $\mathrm{G}_{1} / \mathrm{S}$ and $\mathrm{S} / \mathrm{G}_{2}$, through p53-independent and dependent pathways [185]. Moreover, p21 and p27 are the key contributors in the cell-cycle regulation of $\mathrm{CD} 34^{+} \mathrm{HPCs}$ [186-188]. Tax1 has also been shown to suppress human mitotic checkpoint protein MAD1 resulting in deregulation of the G2/M phase of the cell cycle resulting in aneuploidy [189]

Cell cycle progression is highly regulated in CD34 ${ }^{+}$ HPCs with a majority of $\mathrm{CD} 34^{+}$HPCs residing in quiescence and demonstrating a unique expression pattern of CDKs, cyclins, and CDK inhibitors. The CDK inhibitors p21 and p27, in particular, have been shown to be key contributors in restricting cell cycle entry from $G_{0}$ and maintaining quiescence in CD34 ${ }^{+}$HPCs [186-188]. We have previously shown that during HTLV-1 infection, induction of $G_{0} / G_{1}$ cell cycle arrest and suppression of multilineage hematopoiesis in HPCs is attributed to the concomitant activation of p21 and p27 in these cells by Tax1 $[63,64,180]$. Although Tax1 usually induces cellular gene expression by activation of transcription factors such as NF- $\kappa$ B, CREB/ATF and Akt [190], it has recently been suggested that $\operatorname{Tax} 1$ deregulation of $\mathrm{p} 21$ and p27 may also be mediated independently of NF- $\kappa \mathrm{B}$ activation [191] and p53 [184]. Moreover, the reported absence of NF- $\kappa$ B activity in CD34 ${ }^{+}$CD38 ${ }^{-}$HSCs [192] suggests that HP/HSCs provide a unique microenvironment for HTLV-1 infection which stands in stark contrast to the cellular environment provided by mature $\mathrm{CD} 4^{+} \mathrm{T}$ lymphocytes. It may be inferred that Tax1mediated cell cycle deregulation is cell-type specific, inducing cell cycle arrest in HPCs while concurrently maintaining the ability to activate cell proliferation in mature $\mathrm{CD} 4^{+} \mathrm{T}$-lymphocytes.

Survivin, originally identified as a member of the inhibitor of apoptosis protein family, has recently been implicated in regulating hematopoiesis, cell cycle control and transformation [193-196]. Survivin is expressed in normal adult bone marrow cells and in CD34 ${ }^{+}$HPCs where it regulates proliferation and/or survival, and survivin expression is upregulated by hematopoietic growth factors [197]. Notably, survivin has been shown to be a key mediator of early cell cycle entry in CD $34^{+}$HPCs and regulates progenitor cell proliferation through p21dependent and independent pathways [198], in addition to regulating apoptosis of HSCs [199]. This implicates survivin as an integral cellular factor, regulating multiple aspects of hematopoiesis. HTLV-1 mediated suppression of hematopoiesis in CD34 $4^{+}$HPCs is regulated, in part, by down-regulation of survivin expression in these cells by Tax 1 [64]. Notably, CD $34^{+} \mathrm{CD} 38^{-}$HSCs demonstrate 
elevated sensitivity to cell-cycle arrest following HTLV-1 infection in comparison to more mature $\mathrm{CD} 34^{+} \mathrm{CD} 38^{+}$ HPCs, suggesting that HTLV-1 may target stem cells to facilitate a latent infection in vivo by inducing cell cycle arrest to induce cellular quiescence (Figure 4).

\section{HTLV-1 Interaction with CD34 ${ }^{+}$HP/HSCs: Emerging Views}

Emerging evidence has led to a new view of HTLV-1 mediated leukemogenesis that correlates neonatal transmission of HTLV-1 with viral infection targeting of HP/ HSCs and immature human thymocytes $[63,65,115]$. This hypothesis challenges the current view that mature differentiated $\mathrm{CD}_{4}{ }^{+} \mathrm{T}$-cells are the exclusive target for HTLV-1 infection and for the initiation of ATLL.
Analysis of bone marrow samples from pediatric HTLV1 infections would confirm the hypothesis that HTLV-1 infection enters and is sequestered in the $\mathrm{CD} 34^{+} \mathrm{HP} /$ HSCs in the bone marrow. It is noteworthy that previous reports have demonstrated HTLV-1 transmission following a bone marrow transplantation procedure from a HTLV-1 infected donor [200]. HTLV-1 infection of HP/HSCs can result in skewing of hematopoiesis toward distinct cellular lineages and outgrowth of malignant clones leading to ATLL. HP/HSCs may be critical target cell for HTLV-1 infection and for establishment of latency in vivo providing a reservoir of infected cells which progresses, after the accumulation of additional molecular events, to the development of ATLL $[62,65]$. This hypothesis is supported by recent identification of

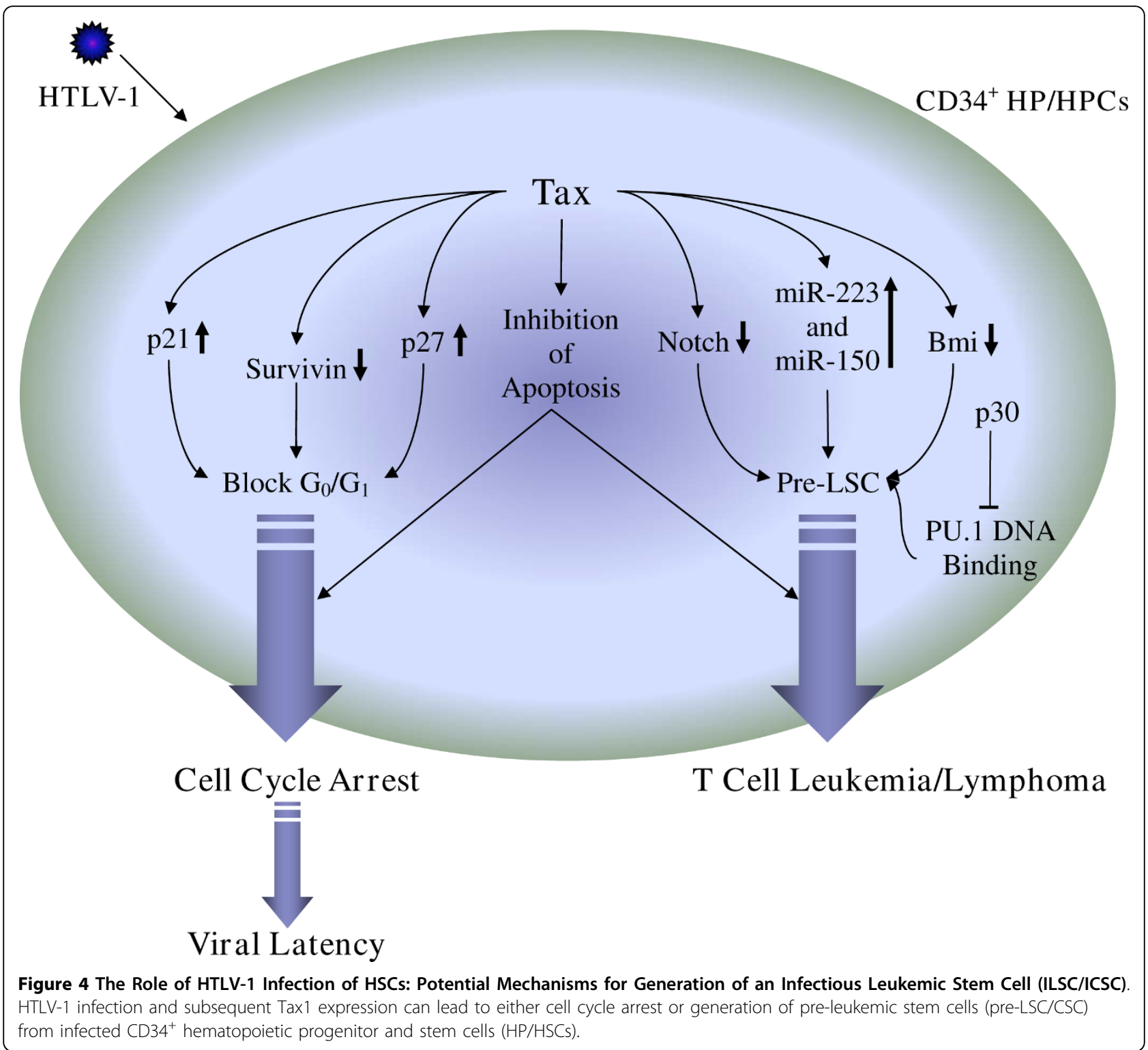


a rare CSC population in Tax-transgenic mice $[6,128]$. Notably, our laboratory has detected a high incidence of HTLV-1 proviral sequences in CD $34^{+} \mathrm{HP} / \mathrm{HSCs}$ from HTLV-1-infected patient peripheral blood lymphocyte samples, suggesting that $\mathrm{HP} / \mathrm{HSCs}$ are a natural cellular reservoir for HTLV-1 infection [131]. The down-regulation of key hematopoietic genes, including Notch1 and Bmi-1, in CSCs from Tax-transgenic mice indicates that the CSC potentially emerges from primitive HPCs or immature thymocytes and highlights the role of Tax1 expression in the induction of lymphoproliferative disease (Figure 4). The role of HTLV-1 Tax in HP/HSCs includes cell cycle deregulation and perturbation of hematopoiesis, as we have previously reported $[63,180]$. Clearly many parameters defining how HTLV-1 and its associated viral genes (including Tax1, p30 and HBZ [201]), may contribute to the development of a ILSC/ ICSC in ATLL have yet to be established. The role of the HTLV-1 antisense encoded protein HBZ is of particular interest as it is consistently expressed in all ATLL patient cells examined in contrast to Tax 1 which is usually silenced in ATLL cells [202,203]. Emerging in vivo murine models, particularly the HU-SCID mouse models, will help characterize the pathobiology of HTLV-1 infection and establish the existence of ILSC/ ICSC. Moreover, these models will allow for the identification of events resulting in leukemia-initiation and progression and for the pre-clinical therapeutic evaluation for this fatal malignancy which currently lacks effective treatment regimens.

\section{Perspectives}

Retroviral infection of HP/HSCs in the bone marrow clearly provides a reservoir for infected cells and results in dramatically altered patterns of hematopoiesis. Determining and identifying whether retroviruses, such as HTLV-1, exploit this cellular trait to establish an ILSC would present a new paradigm in the pathobiology of HTLV-1 infection and would allow novel targeted treatments to be designed in order to intervene and treat retroviral mediated neoplasms.

\footnotetext{
Abbreviations

LSC/CSC: leukemic stem cell/cancer stem cell; HP/HSC: hematopoietic progenitor/stem cell; HTLV-1: human T cell lymphotropic virus type 1; ILSC/ ICSC: infectious leukemic/cancer stem cell; CLP: common lymphoid progenitor; CMP: common myeloid progenitor; $\mathrm{AML}$ : acute myeloid leukemia; ALL: acute lymphoblastic leukemia; CML: chronic myelogenous leukemia; HU-SCID mouse: humanized severe combined immunodeficient mouse; HIV-1: human immunodeficiency virus type-1; FLV: Friend leukemia virus; M-MuLV: Moloney murine leukemia virus; AEV: Avian erythroblastosis virus; BLV: Bovine leukemia virus; ATLL: Adult T cell leukemia/lymphoma; CREB/ATF: cyclic AMP response element-binding protein/activating transcription factor; Bmi-1: B-lymphoma Mo-MuLV insertion region; DN: double negative; DP: double positive; miRNAs: micro-RNAs.
}

\section{Acknowledgements}

This work was supported by grants from the US National Institutes of Health (CA124595) and by the Empire State Stem Cell Fund through New York State Department of Health Contract (NYSTEM \#C023059 and \#N08G-127) to G.F. Opinions expressed here are solely those of the author and do not necessarily reflect those of the Empire State Stem Cell Board, the New York State Department of Health, or the State of New York.

\section{Author details}

'Department of Microbiology and Immunology, SUNY Upstate Medical University, Syracuse, NY, 13210, USA. ${ }^{2}$ Center for Humanized SCID Mice and Stem Cell Processing Laboratory, SUNY Upstate Medical University, Syracuse, NY, 13210, USA.

\section{Authors' contributions}

PB and LC were responsible for drafting and revising the manuscript as well as organizing the content. ES created Figures 1, 2, 3 and 4 and their legends and proofread the final version of the manuscript for content and consistency. GF assisted in all aspects of writing the manuscript from revisions to final approval of the version to be published. All authors read and approved the final manuscript.

\section{Competing interests}

The authors declare that they have no competing interests.

Received: 1 October 2009

Accepted: 4 February 2010 Published: 4 February 2010

\section{References}

1. Kondo M, Wagers AJ, Manz MG, Prohaska SS, Scherer DC, Beilhack GF, Shizuru JA, Weissman IL: Biology of Hematopoietic Stem Cells and Progenitors: Implications for Clinical Application. Annual Review of Immunology 2003, 21:759-806.

2. Reya T, Morrison SJ, Clarke MF, Weissman IL: Stem cells, cancer, and cancer stem cells. Nature 2001, 414:105-111.

3. Maciejewski JP, Bruening EE, Donahue RE, Mocarski ES, Young NS, St Jeor SC: Infection of hematopoietic progenitor cells by human cytomegalovirus. Blood 1992, 80:170-178.

4. Manchester M, Smith KA, Eto DS, Perkin HB, Torbett BE: Targeting and hematopoietic suppression of human CD34+ cells by measles virus. $J$ Virol 2002, 76:6636-6642.

5. Goodrum F, Jordan CT, Terhune SS, High K, Shenk T: Differential outcomes of human cytomegalovirus infection in primitive hematopoietic cell subpopulations. Blood 2004, 104:687-695.

6. Yamazaki J, Mizukami T, Takizawa K, Kuramitsu M, Momose H, Masumi A, Ami Y, Hasegawa H, Hall WW, Tsujimoto H, Hamaguchi I, Yamaguchi K: Identification of cancer stem cells in a Tax-transgenic (Tax-Tg) mouse model of adult T- cell leukemia/lymphoma (ATL). Blood 2009, 114(13):2709-20.

7. Jordan $\mathrm{CT}$, Guzman ML, Noble M: Cancer Stem Cells. The New England Journal of Medicine 2006, 355:1253-1261.

8. Huang S, Terstappen LW: Lymphoid and myeloid differentiation of single human CD34+, HLA-DR+, CD38- hematopoietic stem cells. Blood 1994, 83:1515-1526.

9. Allen TD, Dexter TM: The essential cells of the hemopoietic microenvironment. Exp Hematol 1984, 12:517-521.

10. Laiosa CV, Stadtfeld M, Graf T: Determinants of lymphoid-myeloid lineage diversification. Annu Rev Immunol 2006, 24:705-738.

11. Ogawa M: Differentiation and proliferation of hematopoietic stem cells. Blood 1993, 81:2844-2853.

12. Galy A, Travis M, Cen D, Chen B: Human T, B:natural killer, and dendritic cells arise from a common bone marrow progenitor cell subset. Immunity 1995, 3:459-473.

13. Ikawa T, Kawamoto H, Fujimoto S, Katsura Y: Commitment of common T/ Natural killer (NK) progenitors to unipotent T and NK progenitors in the murine fetal thymus revealed by a single progenitor assay. J Exp Med 1999, 190:1617-1626.

14. Akashi $K$, Traver D, Miyamoto T, Weissman IL: A clonogenic common myeloid progenitor that gives rise to all myeloid lineages. Nature 2000, 404:193-197. 
15. Weissman IL, Shizuru JA: The origins of the identification and isolation of hematopoietic stem cells, and their capability to induce donor-specific transplantation tolerance and treat autoimmune diseases. Blood 2008, 112:3543-3553.

16. Metcalf $\mathrm{D}$ : The molecular control of cell division, differentiation commitment and maturation in haemopoietic cells. Nature 1989, 339:27-30.

17. Chao MP, Seita J, Weissman IL: Establishment of a Normal Hematopoietic and Leukemia Stem Cell Hierarchy. Cold Spring Harb Symp Quant Biol 2008.

18. Wright DE, Wagers AJ, Gulati AP, Johnson FL, Weissman IL: Physiological migration of hematopoietic stem and progenitor cells. Science 2001, 294:1933-1936.

19. Sell S, Pierce GB: Maturation arrest of stem cell differentiation is a common pathway for the cellular origin of teratocarcinomas and epithelial cancers. Lab Invest 1994, 70:6-22.

20. Sawyers $C L$, Denny $C T$, Witte $O N$ : Leukemia and the disruption of normal hematopoiesis. Cell 1991, 64:337-350.

21. Ellisen LW, Carlesso N, Cheng T, Scadden DT, Haber DA: The Wilms tumor suppressor WT1 directs stage-specific quiescence and differentiation of human hematopoietic progenitor cells. Embo J 2001, 20:1897-1909.

22. Fialkow PJ, Singer JW, Adamson JW, Vaidya K, Dow LW, Ochs J, Moohr JW: Acute nonlymphocytic leukemia: heterogeneity of stem cell origin. Blood 1981, 57:1068-1073.

23. Wang JC, Dick JE: Cancer stem cells: lessons from leukemia. Trends Cell Biol 2005, 15:494-501.

24. Renneville A, Roumier C, Biggio V, Nibourel O, Boissel N, Fenaux P, Preudhomme C: Cooperating gene mutations in acute myeloid leukemia: a review of the literature. Leukemia 2008, 22:915-931.

25. Lapidot T, Sirard C, Vormoor J, Murdoch B, Hoang T, Caceres-Cortes J, Minden M, Paterson B, Caligiuri MA, Dick JE: A cell initiating human acute myeloid leukaemia after transplantation into SCID mice. Nature 1994, 367:645-648

26. Zhu AJ, Watt FM: beta-catenin signalling modulates proliferative potential of human epidermal keratinocytes independently of intercellular adhesion. Development 1999, 126:2285-2298.

27. Chan EF, Gat U, McNiff JM, Fuchs E: A common human skin tumour is caused by activating mutations in beta-catenin. Nat Genet 1999, 21:410-413.

28. Jamieson CH, Ailles LE, Dylla SJ, Muiitjens M, Jones C, Zehnder JL, Gotlib J, Li K, Manz MG, Keating A, Sawyers CL, Weissman IL: Granulocytemacrophage progenitors as candidate leukemic stem cells in blast-crisis CML. N Engl J Med 2004, 351:657-667.

29. Sirard C, Lapidot T, Vormoor J, Cashman JD, Doedens M, Murdoch B, Jamal N, Messner H, Addey L, Minden M, Laraya P, Keating A, Eaves A, Lansdorp PM, Eaves CJ, Dick JE: Normal and leukemic SCID-repopulating cells (SRC) coexist in the bone marrow and peripheral blood from CML patients in chronic phase, whereas leukemic SRC are detected in blast crisis. Blood 1996, 87:1539-1548.

30. Bjerkvig R, Tysnes BB, Aboody KS, Najbauer J, Terzis AJ: Opinion: the origin of the cancer stem cell: current controversies and new insights. Nat Rev Cancer 2005, 5:899-904.

31. Bonnet $D$, Dick JE: Human acute myeloid leukemia is organized as a hierarchy that originates from a primitive hematopoietic cell. Nat Med 1997, 3:730-737.

32. Custer RP, Basma GC, Bosma MJ: Severe Combined Immunodeficiency (SCID) in the Mouse: Pathology, Reconstitution, Neoplasms. American Journal of Pathology 1985, 120:464-477.

33. Deshpande AJ, Buske C: Lymphoid Progenitors as Candidate Cancer Stem Cells in AML. Cell Cycle 2007, 6:543-545.

34. Hope KJ, Jin L, Dick JE: Human Acute Myeloid Leukemia Stem Cells. Archives of Medical Research 2003, 34:507-514.

35. Chan W-I, Huntly BJP: Leukemia Stem Cells in Acute Myeloid Leukemia. Seminars in Oncology 2008, 35:326-335.

36. Tan BT, Park CY, Ailles LE, Weissman IL: The cancer stem cell hypothesis: a work in progress. Lab Invest 2006, 86:1203-1207.

37. McCulloch EA: Stem cells in normal and leukemic hemopoiesis (Henry Stratton Lecture, 1982). Blood 1983, 62:1-13.

38. Kosmider O, Moreau-Gachelin F: From mice to human: the "two-hit model" of leukemogenesis. Cell Cycle 2006, 5:569-570.

39. Keller G: Hematopoietic stem cells. Curr Opin Immunol 1992, 4:133-139.
40. Till JE, McCulloch EA: Hemopoietic stem cell differentiation. Biochim Biophys Acta 1980, 605:431-459.

41. Kolb-Maurer A, Goebel W: Susceptibility of hematopoietic stem cells to pathogens: role in virus/bacteria tropism and pathogenesis. FEMS Microbiol Lett 2003, 226:203-207.

42. Segovia JC, Guenechea G, Gallego JM, Almendral JM, Bueren JA: Parvovirus infection suppresses long-term repopulating hematopoietic stem cells. J Virol 2003, 77:8495-8503.

43. Sansonno D, Lotesoriere C, Cornacchiulo V, Fanelli M, Gatti P, lodice G, Racanelli V, Dammacco F: Hepatitis C virus infection involves CD34(+) hematopoietic progenitor cells in hepatitis $\mathrm{C}$ virus chronic carriers. Blood 1998, 92:3328-3337.

44. Monaco MC, Atwood WJ, Gravell M, Tornatore CS, Major EO: JC virus infection of hematopoietic progenitor cells, primary B lymphocytes, and tonsillar stromal cells: implications for viral latency. J Virol 1996, 70:7004-7012.

45. Movassagh M, Gozlan J, Senechal B, Baillou C, Petit JC, Lemoine FM: Direct infection of $\mathrm{CD} 34+$ progenitor cells by human cytomegalovirus: evidence for inhibition of hematopoiesis and viral replication. Blood 1996, 88:1277-1283.

46. Sindre $H$, Tjoonnfjord GE, Rollag $H$, Ranneberg-Nilsen T, Veiby OP, Beck S, Degre $M$, Hestdal $K$ : Human cytomegalovirus suppression of and latency in early hematopoietic progenitor cells. Blood 1996, 88:4526-4533.

47. Zhuravskaya T, Maciejewski JP, Netski DM, Bruening E, Mackintosh FR, St Jeor S: Spread of human cytomegalovirus (HCMV) after infection of human hematopoietic progenitor cells: model of HCMV latency. Blood 1997, 90:2482-2491.

48. Khaiboullina SF, Maciejewski JP, Crapnell K, Spallone PA, Dean Stock A, Pari GS, Zanjani ED, Jeor SS: Human cytomegalovirus persists in myeloid progenitors and is passed to the myeloid progeny in a latent form. $\mathrm{Br} J$ Haematol 2004, 126:410-417.

49. Isomura H, Yamada M, Yoshida M, Tanaka H, Kitamura T, Oda M, Nii S, Seino $Y$ : Suppressive effects of human herpesvirus 6 on in vitro colony formation of hematopoietic progenitor cells. J Med Virol 1997, 52:406-412.

50. Isomura H, Yoshida M, Namba H, Fujiwara N, Ohuchi R, Uno F, Oda M, Seino Y, Yamada M: Suppressive effects of human herpesvirus-6 on thrombopoietin-inducible megakaryocytic colony formation in vitro. $J$ Gen Virol 2000, 81:663-673.

51. Mirandola P, Secchiero P, Pierpaoli S, Visani G, Zamai L, Vitale M, Capitani S, Zauli G: Blood 2000, 96:126-131.

52. Wu W, Vieira J, Fiore N, Banerjee P, Sieburg M, Rochford R, Harrington W Jr, Feuer G: KSHV/HHV-8 infection of human hematopoietic progenitor (CD34+) cells: persistence of infection during hematopoiesis in vitro and in vivo. Blood 2006, 108:141-151.

53. Sinzger C, Grefte A, Plachter B, Gouw AS, The TH, Jahn G: Fibroblasts, epithelial cells, endothelial cells and smooth muscle cells are major targets of human cytomegalovirus infection in lung and gastrointestinal tissues. J Gen Virol 1995, 76(Pt 4):741-750.

54. Soderberg C, Larsson S, Bergstedt-Lindqvist S, Moller E: Definition of a subset of human peripheral blood mononuclear cells that are permissive to human cytomegalovirus infection. J Virol 1993, 67:3166-3175

55. Soderberg C, Larsson S, Bergstedt-Lindqvist S, Moller E: Identification of blood mononuclear cells permissive of cytomegalovirus infection in vitro. Transplant Proc 1993, 25:1416-1418.

56. Schrier RD, Nelson JA, Oldstone MB: Detection of human cytomegalovirus in peripheral blood lymphocytes in a natural infection. Science 1985, 230:1048-1051

57. Maciejewski JP, St Jeor SC: Human cytomegalovirus infection of human hematopoietic progenitor cells. Leuk Lymphoma 1999, 33:1-13.

58. Mendelson M, Monard S, Sissons P, Sinclair J: Detection of endogenous human cytomegalovirus in CD34+ bone marrow progenitors. J Gen Virol 1996, 77(Pt 12):3099-3102.

59. Taylor-Wiedeman J, Sissons JG, Borysiewicz LK, Sinclair JH: Monocytes are a major site of persistence of human cytomegalovirus in peripheral blood mononuclear cells. J Gen Virol 1991, 72(Pt 9):2059-2064.

60. Hahn G, Jores R, Mocarski ES: Cytomegalovirus remains latent in a common precursor of dendritic and myeloid cells. Proc Natl Acad Sci USA 1998, 95:3937-3942. 
61. von Laer D, Meyer-Koenig U, Serr A, Finke J, Kanz L, Fauser AA, NeumannHaefelin D, Brugger W, Hufert FT: Detection of cytomegalovirus DNA in CD34+ cells from blood and bone marrow. Blood 1995, 86:4086-4090.

62. Grant C, Barmak K, Alefantis T, Yao J, Jacobson S, Wigdahl B: Human T cell leukemia virus type I and neurologic disease: events in bone marrow, peripheral blood, and central nervous system during normal immune surveillance and neuroinflammation. J Cell Physiol 2002, 190:133-159.

63. Tripp A, Banerjee P, Sieburg M, Planelles V, Li F, Feuer G: Induction of cell cycle arrest by human T-cell lymphotropic virus type 1 Tax in hematopoietic progenitor (CD34+) cells: modulation of p21cip1/waf1 and p27kip1 expression. J Virol 2005, 79:14069-14078.

64. Banerjee P, Sieburg M, Samuelson E, Feuer G: Human T-cell lymphotropic virus type 1 infection of CD34+ hematopoietic progenitor cells induces cell cycle arrest by modulation of p21(cip1/waf1) and survivin. Stem Cells 2008, 26:3047-3058.

65. Feuer G, Fraser JK, Zack JA, Lee F, Feuer R, Chen IS: Human T-cell leukemia virus infection of human hematopoietic progenitor cells: maintenance of virus infection during differentiation in vitro and in vivo. J Virol 1996, 70:4038-4044.

66. Folks TM, Kessler SW, Orenstein JM, Justement JS, Jaffe ES, Fauci AS: Infection and replication of HIV-1 in purified progenitor cells of normal human bone marrow. Science 1988, 242:919-922.

67. Fan H: Leukemogenesis by Moloney murine leukemia virus: a multistep process. Trends Microbiol 1997, 5:74-82.

68. Moreau-Gachelin F, Wendling F, Molina T, Denis N, Titeux M, Grimber G, Briand P, Vainchenker W, Tavitian A: Spi-1/PU.1 transgenic mice develop multistep erythroleukemias. Mol Cell Biol 1996, 16:2453-2463.

69. Beug $H$, Bauer A, Dolznig H, von Lindern M, Lobmayer L, Mellitzer G, Steinlein P, Wessely O, Mullner E: Avian erythropoiesis and erythroleukemia: towards understanding the role of the biomolecules involved. Biochim Biophys Acta 1996, 1288:M35-47.

70. Zauli G, Vitale M, Re MC, Furlini G, Zamai L, Falcieri E, Gibellini D, Visani G, Davis BR, Capitani $S$, et al: In vitro exposure to human immunodeficiency virus type 1 induces apoptotic cell death of the factor-dependent TF-1 hematopoietic cell line. Blood 1994, 83:167-175.

71. Moreau-Gachelin F, Robert-Lezenes J, Wendling F, Tavitian A, Tambourin P: Integration of spleen focus-forming virus proviruses in Friend tumor cells. J Virol 1985, 53:292-295.

72. Brightman BK, Davis BR, Fan H: Preleukemic hematopoietic hyperplasia induced by Moloney murine leukemia virus is an indirect consequence of viral infection. J Virol 1990, 64:4582-4584.

73. Moses AV, Williams S, Heneveld ML, Strussenberg J, Rarick M, Loveless M, Bagby G, Nelson JA: Human immunodeficiency virus infection of bone marrow endothelium reduces induction of stromal hematopoietic growth factors. Blood 1996, 87:919-925.

74. Speck NA, Gilliland DG: Core-binding factors in haematopoiesis and leukaemia. Nat Rev Cancer 2002, 2:502-513.

75. Gilliland DG, Griffin JD: The roles of FLT3 in hematopoiesis and leukemia. Blood 2002, 100:1532-1542.

76. Tenen DG: Disruption of differentiation in human cancer: AML shows the way. Nat Rev Cancer 2003, 3:89-101

77. Reilly JT: Pathogenesis of acute myeloid leukaemia and inv(16)(p13;q22): a paradigm for understanding leukaemogenesis?. Br J Haematol 2005, 128:18-34

78. Rosenbauer F, Koschmieder S, Steidl U, Tenen DG: Effect of transcriptionfactor concentrations on leukemic stem cells. Blood 2005, 106:1519-1524.

79. Gilliland DG: Hematologic malignancies. Curr Opin Hematol 2001, 8:189-191.

80. Moreau-Gachelin F: Lessons from models of murine erythroleukemia to acute myeloid leukemia (AML): proof-of-principle of co-operativity in AML. Haematologica 2006, 91:1644-1652.

81. Rulli K, Lenz J, Levy LS: Disruption of hematopoiesis and thymopoiesis in the early premalignant stages of infection with SL3-3 murine leukemia virus. J Virol 2002, 76:2363-2374.

82. Schroeder C, Gibson L, Nordstrom C, Beug H: The estrogen receptor cooperates with the TGF alpha receptor (c-erbB) in regulation of chicken erythroid progenitor self-renewal. Embo J 1993, 12:951-960.

83. Ruscetti SK: Erythroleukaemia induction by the Friend spleen focusforming virus. Baillieres Clin Haematol 1995, 8:225-247.

84. Moreau-Gachelin F: Multi-stage Friend murine erythroleukemia: molecular insights into oncogenic cooperation. Retrovirology 2008, 5:99.
85. Friend C: Cell-free transmission in adult Swiss mice of a disease having the character of a leukemia. J Exp Med 1957, 105:307-318.

86. Tambourin P, Wendling F: Malignant transformation and erythroid differentiation by polycythaemia-inducing Friend virus. Nat New Biol 1971, 234:230-233.

87. Axelrad AA, Steeves RA: Assay for Friend Leukemia Virus: Rapid Quantitative Method Based on Enumeration of Macroscopic Spleen Foci in Mice. Virology 1964, 24:513-518.

88. Fredrickson T, Tambourin P, Wendling F, Jasmin C, Smajda F: Target cell of the polycythemia-inducing Friend virus: studies with myleran. J Natl Cancer Inst 1975, 55:443-446.

89. Zon LI, Moreau JF, Koo JW, Mathey-Prevot B, D'Andrea AD: The erythropoietin receptor transmembrane region is necessary for activation by the Friend spleen focus-forming virus gp55 glycoprotein. Mol Cell Biol 1992, 12:2949-2957.

90. Li JP, Hu HO, Niu QT, Fang C: Cell surface activation of the erythropoietin receptor by Friend spleen focus-forming virus gp55. J Virol 1995, 69:1714-1719.

91. Moreau-Gachelin F, Tavitian A, Tambourin P: Spi-1 is a putative oncogene in virally induced murine erythroleukaemias. Nature 1988, 331:277-280.

92. Kastner P, Chan S: PU.1: a crucial and versatile player in hematopoiesis and leukemia. Int J Biochem Cell Biol 2008, 40:22-27.

93. Brightman BK, Chandy KG, Spencer RH, Gupta S, Pattengale PK, Fan H: Characterization of lymphoid tumors induced by a recombinant murine retrovirus carrying the avian v-myc oncogene. Identification of novel (Blymphoid) tumors in the thymus. J Immunol 1988, 141:2844-2854.

94. Lazo PA, Klein-Szanto AJ, Tsichlis PN: T-cell lymphoma lines derived from rat thymomas induced by Moloney murine leukemia virus: phenotypic diversity and its implications. J Virol 1990, 64:3948-3959.

95. Buckheit RW Jr, Kurtzberg J, Bolognesi DP, Weinhold KJ: The coenrichment of stem cells, prothymocytes, and stromal elements with ecotropic retrovirus-producing cells from the bone marrow of leukemia-prone AKR mice. Virology 1988, 162:354-361.

96. Haran-Ghera N: Potential leukemic cells among bone marrow cells of young AKR/J mice. Proc Natl Acad Sci USA 1980, 77:2923-2926.

97. Haran-Ghera N, Rubio N, Leef F, Goldstein G: Characteristics of preleukemia cells induced in mice. Cell Immunol 1978, 37:308-314.

98. Belli B, Fan H: The leukemogenic potential of an enhancer variant of Moloney murine leukemia virus varies with the route of inoculation. J Virol 1994, 68:6883-6889.

99. Fan H, Brightman BK, Belli B, Okimoto M, Tao M: Early (preleukemic) events in Moloney murine leukemia virus leukemogenesis. Leukemia 1997, 11(Suppl 3):149-151.

100. Li QX, Fan H: Combined infection by Moloney murine leukemia virus and a mink cell focus-forming virus recombinant induces cytopathic effects in fibroblasts or in long-term bone marrow cultures from preleukemic mice. J Virol 1990, 64:3701-3711.

101. Burny A, Bruck C, Cleuter Y, Couez D, Deschamps J, Ghysdael J, Gregoire D, Kettmann R, Mammerickx M, Marbaix G, et al: Bovine Leukemia Virus, a Versatile Agent with Various Pathogenic Effects in Various Animal Species. Cancer Research 1985, 45:4578s-4582.

102. Gillet N, Florins A, Boxus M, Burteau C, Nigro A, Vandermeers F, Balon $H_{4}$ Bouzar A-B, Defoiche J, Burny A, Reichert M, Kettmann R, Willems L: Mechanisms of leukemogenesis induced by bovine leukemia virus: prospects for novel anti-retroviral therapies in human. Retrovirology 2007, 4:18.

103. Gallo RC, Wong-Staal F: Retroviruses as Etiologic Agents of Some Animal and Human Leukemias and Lymphomas and as Tools for Elucidating the Molecular Mechanism of Leukemogenesis. Blood 1982, 60:545-555.

104. Stone DM, Norton LK, Davis WC: Spontaneously proliferating lymphocytes from bovine leukaemia virus-infected, lymphocytic cattle are not the virus-expressing lymphocytes, as these cells are delayed in G0/G1 of the cell cycle and are spared from apoptosis. Journal of General Virology 2000, 81:971-981.

105. Mirsky ML, Olmstead CA, Da Y, Lewin HA: The Prevalence of Proviral Bovine Leukemia Virus in Peripheral Blood Mononuclear Cells at Two Subclinical Stages of Infection. Journal of Virology 1996, 70:2178-2183.

106. Meirom R, Moss S, Brenner J: Bovine leukemia virus-gp51 antigen expression is associated with CD5 and IgM markers on infected lymphocytes. Veterinary Immunology and Immunopathology 1997, 59:113-119. 
107. Moules V, Pomier C, Sibon D, Gabet A-S, Reichert M: Fate of Premalignant Clones during the Asymptomatic Phase Preceeding Lymphoid Malignancy. Cancer Research 2005, 65:1234-1243.

108. Reilly JT: FLT3 and its role in the pathogenesis of acute myeloid leukaemia. Leuk Lymphoma 2003, 44:1-7.

109. Michaud J, Scott HS, Escher R: AML1 interconnected pathways of leukemogenesis. Cancer Investigation 2003, 21:105-136.

110. Poiesz BJ, Ruscetti FW, Gazdar AF, Bunn PA, Minna JD, Gallo RC: Detection and isolation of type $C$ retrovirus particles from fresh and cultured lymphocytes of a patient with cutaneous T-cell lymphoma. Proc Natl Acad Sci USA 1980, 77:7415-7419.

111. Matsuoka M, Jeang KT: Human T-cell leukaemia virus type 1 (HTLV-1) infectivity and cellular transformation. Nat Rev Cancer 2007, 7:270-280.

112. Mortreux F, Gabet AS, Wattel E: Molecular and cellular aspects of HTLV-1 associated leukemogenesis in vivo. Leukemia 2003, 17:26-38

113. Matsuoka M: Human T-cell leukemia virus type I and adult T-cell leukemia. Oncogene 2003, 22:5131-5140.

114. Takatsuki K: Discovery of adult T-cell leukemia. Retrovirology 2005, 2:16.

115. Wencker M, Sausse C, Derse D, Gazzolo L, Duc Dodon M: Human T-cell leukemia virus type 1 Tax protein down-regulates pre-T-cell receptor alpha gene transcription in human immature thymocytes. J Virol 2007, 81:301-308.

116. Boxus M, Twizere JC, Legros S, Dewulf JF, Kettmann R, Willems L: The HTLV-1 Tax interactome. Retrovirology 2008, 5:76.

117. Jeang KT, Giam CZ, Majone F, Aboud M: Life, death, and tax: role of HTLVI oncoprotein in genetic instability and cellular transformation. J Biol Chem 2004, 279:31991-31994.

118. Sun SC, Ballard DW: Persistent activation of NF-kappaB by the tax transforming protein of HTLV-1: hijacking cellular IkappaB kinases. Oncogene 1999, 18:6948-6958.

119. Jeang KT, Widen SG, Semmes OJt, Wilson SH: HTLV-I trans-activator protein, tax, is a trans-repressor of the human beta-polymerase gene. Science 1990, 247:1082-1084.

120. Kasai T, Jeang KT: Two discrete events, human T-cell leukemia virus type I Tax oncoprotein expression and a separate stress stimulus, are required for induction of apoptosis in T-cells. Retrovirology 2004, 1:7.

121. Yoshida M: Multiple viral strategies of HTLV-1 for dysregulation of cell growth control. Annu Rev Immunol 2001, 19:475-496.

122. Brauweiler A, Garrus JE, Reed JC, Nyborg JK: Repression of bax gene expression by the HTLV-1 Tax protein: implications for suppression of apoptosis in virally infected cells. Virology 1997, 231:135-140.

123. Kibler KV, Jeang KT: CREB/ATF-dependent repression of cyclin a by human T-cell leukemia virus type 1 Tax protein. J Virol 2001, 75:2161-2173.

124. Lemasson I, Robert-Hebmann V, Hamaia S, Duc Dodon M, Gazzolo L, Devaux C: Transrepression of Ick gene expression by human T-cell leukemia virus type 1-encoded p40tax. J Virol 1997, 71:1975-1983.

125. Riou P, Bex F, Gazzolo L: The human T cell leukemia/lymphotropic virus type 1 Tax protein represses MyoD-dependent transcription by inhibiting MyoD-binding to the KIX domain of $\mathrm{p} 300$. A potential mechanism for Tax-mediated repression of the transcriptional activity of basic helix-loop-helix factors. J Biol Chem 2000, 275:10551-10560.

126. Suzuki T, Narita T, Uchida-Toita M, Yoshida M: Down-regulation of the INK4 family of cyclin-dependent kinase inhibitors by tax protein of HTLV-1 through two distinct mechanisms. Virology 1999, 259:384-391.

127. Uittenbogaard MN, Giebler HA, Reisman D, Nyborg JK: Transcriptional repression of p53 by human T-cell leukemia virus type I Tax protein. $J$ Biol Chem 1995, 270:28503-28506.

128. Hasegawa H, Sawa H, Lewis MJ, Orba Y, Sheehy N, Yamamoto Y, Ichinohe T, Tsunetsugu-Yokota Y, Katano H, Takahashi H, Matsuda J, Sata T, Kurata T, Nagashima K, Hall WW: Thymus-derived leukemia-lymphoma in mice transgenic for the Tax gene of human T-lymphotropic virus type I. Nat Med 2006, 12:466-472.

129. Ohsugi T, Kumasaka T, Okada S, Urano T: The Tax protein of HTLV-1 promotes oncogenesis in not only immature $T$ cells but also mature $T$ cells. Nat Med 2007, 13:527-528.

130. Yamada Y, Kamihira S, Amagasaki T, Kinoshita K, Kusano M, Chiyoda S, Yawo E, Ikeda S, Suzuyama J, Ichimaru M: Adult T cell leukemia with atypical surface phenotypes: clinical correlation. J Clin Oncol 1985, 3:782-788.
131. Banerjee P, Tripp A, Lairmore M, Crawford L, Sieburg M, Ramos JC, Harrington WJ, Beilke MA, Feuer G: Adult T Cell Leukemia/Lymphoma Development in HTLV-1-Infected Humanized SCID Mice. Blood 2010.

132. Ellisen LW, Bird J, West DC, Soreng AL, Reynolds TC, Smith SD, Sklar J: TAN1, the human homolog of the Drosophila notch gene, is broken by chromosomal translocations in T lymphoblastic neoplasms. Cell 1991, 66:649-661.

133. Weng AP, Ferrando AA, Lee W, Morris JPt, Silverman LB, Sanchez-lrizarry $C$, Blacklow SC, Look AT, Aster JC: Activating mutations of NOTCH1 in human T cell acute lymphoblastic leukemia. Science 2004, 306:269-271.

134. Radtke F, Wilson A, Mancini SJC, MacDonald HR: Notch regulation of lymphocyte development and function. Nat Immunol 2004, 5:247-253.

135. Jundt F, Schwarzer R, Dorken B: Notch signaling in leukemias and lymphomas. Curr Mol Med 2008, 8:51-59.

136. Stier S, Cheng T, Dombkowski D, Carlesso N, Scadden DT: Notch1 activation increases hematopoietic stem cell self-renewal in vivo and favors lymphoid over myeloid lineage outcome. Blood 2002, 99:2369-2378.

137. Wilson A, MacDonald HR, Radtke F: Notch 1-deficient Common Lymphoid Precursors Adopt a B Cell Fate in the Thymus. J Exp Med 2001, 194:1003-1012.

138. Fisher RC, Scott EW: Role of PU.1 in hematopoiesis. Stem Cells 1998, 16:25-37.

139. Klemsz MJ, McKercher SR, Celada A, Van Beveren C, Maki RA: The macrophage and B cell-specific transcription factor PU.1 is related to the ets oncogene. Cell 1990, 61:113-124.

140. Orkin SH: Diversification of Haematopoietic Stem Cells to Specific Lineages. Nature Reviews Genetics 2000, 1:57-64.

141. Stirewalt DL: Fine-tuning PU.1. Nature Genetics 2004, 36:550-551.

142. Ikuta K, Uchida N, Friedman J, Weissman IL: Lymphocyte Development from Stem Cells. Annual Review of Immunology 1992, 10:759-783.

143. McKercher SR, Torbett BE, Anderson KL, Henkel GW, Vestal DJ, Baribault H, Klemsz M, Feeney AJ, Wu GE, Paige CJ, Maki RA: Targeted disruption of the PU.1 gene results in multiple hematopoietic abnormalities. Embo $\mathrm{J}$ 1996, 15:5647-5658.

144. Celada A, Borras FE, Soler C, Lloberas J, Klemsz M, van Beveren C, McKercher S, Maki RA: The transcription factor PU.1 is involved in macrophage proliferation. J Exp Med 1996, 184:61-69.

145. Iwasaki H, Somoza C, Shigematsu H, Duprez EA, Iwasaki-Arai J, Mizuno S, Arinobu Y, Geary K, Zhang P, Dayaram T, Fenyus ML, Elf S, Chan S, Kastner P, Huettner CS, Murray R, Tenen DG, Akashi K: Distinctive and indispensable roles of PU. 1 in maintenance of hematopoietic stem cells and their differentiation. Blood 2005, 106:1590-1600.

146. Dakic A, Metcalf D, Di Rago L, Mifsud S, Wu L, Nutt SL: PU.1 regulates the commitment of adult hematopoietic progenitors and restricts granulopoiesis. J Exp Med 2005, 201:1487-1502.

147. Rosenbauer F, Wagner $K$, Kutok JL, Iwasaki $H$, Le Beau MM, Okuno $Y$, Akashi K, Fiering S, Tenen DG: Acute myeloid leukemia induced by graded reduction of a lineage-specific transcription factor, PU.1. Nat Genet 2004, 36:624-630.

148. Datta A, Sinha-Datta U, Dhillon NK, Buch S, Nicot C: The HTLV-I p30 interferes with TLR4 signaling and modulates the release of pro- and anti-inflammatory cytokines from human macrophages. J Biol Chem 2006, 281:23414-23424.

149. Valk-Lingbeek ME, Bruggeman SW, van Lohuizen M: Stem cells and cancer; the polycomb connection. Cell 2004, 118:409-418

150. Buszczak M, Spradling AC: Searching chromatin for stem cell identity. Cell 2006, 125:233-236.

151. Haupt Y, Alexander WS, Barri G, Klinken SP, Adams JM: Novel zinc finger gene implicated as myc collaborator by retrovirally accelerated lymphomagenesis in E mu-myc transgenic mice. Cell 1991, 65:753-763.

152. Park IK, Qian D, Kiel M, Becker MW, Pihalja M, Weissman IL, Morrison SJ, Clarke MF: Bmi-1 is required for maintenance of adult self-renewing haematopoietic stem cells. Nature 2003, 423:302-305.

153. Lugt van der NM, Domen J, Linders $K$, van Roon M, Robanus-Maandag E, te Riele $H$, Valk van der M, Deschamps J, Sofroniew M, van Lohuizen M, et al: Posterior transformation, neurological abnormalities, and severe hematopoietic defects in mice with a targeted deletion of the bmi-1 proto-oncogene. Genes Dev 1994, 8:757-769.

154. Lessard J, Baban S, Sauvageau G: Stage-specific expression of polycomb group genes in human bone marrow cells. Blood 1998, 91:1216-1224. 
155. Lessard J, Sauvageau G: Bmi-1 determines the proliferative capacity of normal and leukaemic stem cells. Nature 2003, 423:255-260

156. Iwama A, Oguro H, Negishi M, Kato Y, Morita Y, Tsukui H, Ema H, Kamijo T, Katoh-Fukui $Y$, Koseki $H$, van Lohuizen M, Nakauchi H: Enhanced selfrenewal of hematopoietic stem cells mediated by the polycomb gene product Bmi-1. Immunity 2004, 21:843-851.

157. Miyazaki M, Miyazaki K, Itoi M, Katoh Y, Guo Y, Kanno R, Katoh-Fukui Y, Honda H, Amagai T, van Lohuizen M, Kawamoto H, Kanno M: Thymocyte proliferation induced by pre-T cell receptor signaling is maintained through polycomb gene product Bmi-1-mediated Cdkn2a repression. Immunity 2008, 28:231-245.

158. Raaphorst FM: Deregulated expression of Polycomb-group oncogenes in human malignant lymphomas and epithelial tumors. Hum Mol Genet 2005, 14(Spec No 1):R93-R100.

159. Kluiver J, Kroesen BJ, Poppema S, Berg van den A: The role of microRNAs in normal hematopoiesis and hematopoietic malignancies. Leukemia 2006, 20:1931-1936.

160. Garcia P, Frampton J: Hematopoietic lineage commitment: miRNAs add specificity to a widely expressed transcription factor. Dev Cell 2008, 14:815-816.

161. Garzon R, Volinia S, Liu CG, Fernandez-Cymering C, Palumbo T, Pichiorri F, Fabbri M, Coombes K, Alder H, Nakamura T, Flomenberg N, Marcucci G, Calin GA, Kornblau SM, Kantarjian H, Bloomfield CD, Andreeff M, Croce CM: MicroRNA signatures associated with cytogenetics and prognosis in acute myeloid leukemia. Blood 2008, 111:3183-3189.

162. Chen CZ, Li L, Lodish HF, Bartel DP: MicroRNAs Modulate Hematopoietic Lineage Differentiation. Science 2004, 303:83-86.

163. Chen CZ, Lodish HF: MicroRNAs as regulators of mammalian hematopoiesis. Semin Immunol 2005, 17:155-165.

164. Gangaraju VK, Lin H: MicroRNAs: key regulators of stem cells. Nat Rev Mol Cell Biol 2009, 10:116-125.

165. Calin GA, Croce CM: MicroRNA signatures in human cancers. Nat Rev Cancer 2006, 6:857-866.

166. Calin GA, Croce CM: MicroRNA-cancer connection: the beginning of a new tale. Cancer Res 2006, 66:7390-7394.

167. Garzon R, Garofalo M, Martelli MP, Briesewitz R, Wang L, FernandezCymering C, Volinia S, Liu CG, Schnittger S, Haferlach T, Liso A, Diverio D, Mancini M, Meloni G, Foa R, Martelli MF, Mecucci C, Croce CM, Falini B: Distinctive microRNA signature of acute myeloid leukemia bearing cytoplasmic mutated nucleophosmin. Proc Natl Acad Sci USA 2008, 105:3945-3950.

168. Lu J, Guo S, Ebert BL, Zhang H, Peng X, Bosco J, Pretz J, Schlanger R, Wang JY, Mak RH, Dombkowski DM, Preffer Fl, Scadden DT, Golub TR: MicroRNA-mediated control of cell fate in megakaryocyte-erythrocyte progenitors. Dev Cell 2008, 14:843-853.

169. Felli N, Fontana L, Pelosi E, Botta R, Bonci De, Facchiano F, Liuzzi F, Lulli V, Morsilli O, Santoro S, Valtieri M, Calin GA, Liu CG, Sorrentino A, Croce CM, Peschle C: MicroRNAs 221 and 222 inhibit normal erythropoiesis and erythroleukemic cell growth via kit receptor down-modulation. Proceedings of the National Academy of Sciences of the United States of America 2005, 102:18081-18086.

170. Pallasch CP, Patz M, Park YJ, Hagist S, Eggle D, Claus R, Debey-Pascher S, Schulz A, Frenzel LP, Claasen J, Kutsch N, Krause G, Mayr C, Rosenwald A, Plass C, Schultze JL, Hallek M, Wendtner CM: miRNA deregulation by epigenetic silencing disrupts suppression of the oncogene PLAG1 in chronic lymphocytic leukemia. Blood 2009, 114(15):3255-64.

171. Pons A, Nomdedeu B, Navarro A, Gaya A, Gel B, Diaz T, Valera S, Rozman M, Belkaid M, Montserrat E, Monzo M: Hematopoiesis-related microRNA expression in myelodysplastic syndromes. Leuk Lymphoma 2009, 1-6.

172. Strebel K, Luban J, Jeang KT: Human cellular restriction factors that target HIV-1 replication. BMC Med 2009, 7:48.

173. Bouzar $A B$, Willems L: How HTLV-1 may subvert miRNAs for persistence and transformation. Retrovirology 2008, 5:101.

174. Ouellet DL, Plante I, Barat C, Tremblay MJ, Provost P: Emergence of a complex relationship between HIV-1 and the microRNA pathway. Methods Mol Biol 2009, 487:415-433.

175. Pichler K, Schneider G, Grassmann R: MicroRNA miR-146a and further oncogenesis-related cellular microRNAs are dysregulated in HTLV-1transformed T lymphocytes. Retrovirology 2008, 5:100.

176. Yeung ML, Yasunaga J, Bennasser Y, Dusetti N, Harris D, Ahmad N, Matsuoka M, Jeang KT: Roles for microRNAs, miR-93 and miR-130b, and tumor protein 53-induced nuclear protein 1 tumor suppressor in cell growth dysregulation by human T-cell lymphotrophic virus 1. Cancer Res 2008, 68:8976-8985.

177. Bellon M, Lepelletier $Y$, Hermine O, Nicot C: Deregulation of microRNA involved in hematopoiesis and the immune response in HTLV-I adult Tcell leukemia. Blood 2009, 113:4914-4917.

178. Zhou B, Wang S, Mayr C, Bartel DP, Lodish HF: miR-150, a microRNA expressed in mature $B$ and $T$ cells, blocks early $B$ cell development when expressed prematurely. Proc Natl Acad Sci USA 2007, 104:7080-7085.

179. Liu M, Yang L, Zhang L, Liu B, Merling R, Xia Z, Giam CZ: HTLV-1 Infection Leads to Arrest in the G1 phase of the Cell Cycle. J Virol 2008, 82(17):8442-55.

180. Tripp A, Liu Y, Sieburg M, Montalbano J, Wrzesinski S, Feuer G: Human Tcell leukemia virus type 1 tax oncoprotein suppression of multilineage hematopoiesis of CD34+ cells in vitro. J Virol 2003, 77:12152-12164.

181. Liu B, Liang MH, Kuo YL, Liao W, Boros I, Kleinberger T, Blancato J, Giam CZ: Human T-lymphotropic virus type 1 oncoprotein tax promotes unscheduled degradation of $\mathrm{Pds} 1 \mathrm{p} /$ securin and $\mathrm{Clb} 2 \mathrm{p} /$ cyclin $\mathrm{B} 1$ and causes chromosomal instability. Mol Cell Biol 2003, 23:5269-5281.

182. Liu B, Hong S, Tang Z, Yu H, Giam CZ: HTLV-I Tax directly binds the Cdc20-associated anaphase-promoting complex and activates it ahead of schedule. Proc Natl Acad Sci USA 2005, 102:63-68.

183. Kuo YL, Giam CZ: Activation of the anaphase promoting complex by HTLV-1 tax leads to senescence. Embo J 2006, 25:1741-1752.

184. Zhang L, Zhi H, Liu M, Kuo YL, Giam CZ: Induction of p21(CIP1/WAF1) expression by human T-lymphotropic virus type 1 Tax requires transcriptional activation and mRNA stabilization. Retrovirology 2009, 6:35.

185. Macleod KF, Sherry N, Hannon G, Beach D, Tokino T, Kinzler K, Vogelstein B, Jacks T: p53-dependent and independent expression of p21 during cell growth, differentiation, and DNA damage. Genes Dev 1995, 9:935-944.

186. Furukawa Y: Cell cycle control genes and hematopoietic cell differentiation. Leuk Lymphoma 2002, 43:225-231.

187. Cheng T, Rodrigues N, Dombkowski D, Stier S, Scadden DT: Stem cell repopulation efficiency but not pool size is governed by p27(kip1). Nat Med 2000, 6:1235-1240

188. Cheng T, Rodrigues $N$, Shen $H$, Yang $Y$, Dombkowski D, Sykes $M$, Scadden DT: Hematopoietic stem cell quiescence maintained by p21cip1/waf1. Science 2000, 287:1804-1808.

189. Jin DY, Spencer $F$, Jeang KT: Human T cell leukemia virus type 1 oncoprotein Tax targets the human mitotic checkpoint protein MAD1. Cell 1998, 93:81-91.

190. Peloponese JM, Kinjo T, Jeang KT: Human T-cell leukemia virus type 1 tax and cellular transformation. Int J Hematol 2007, 86:101-106.

191. Merling R, Chen C, Hong S, Zhang L, Liu M, Kuo YL, Giam CZ: HTLV-1 Tax mutants that do not induce $\mathrm{G} 1$ arrest are disabled in activating the anaphase promoting complex. Retrovirology 2007, 4:35.

192. Guzman ML, Neering SJ, Upchurch D, Grimes B, Howard DS, Rizzieri DA, Luger SM, Jordan CT: Nuclear factor-kappaB is constitutively activated in primitive human acute myelogenous leukemia cells. Blood 2001, 98:2301-2307.

193. Ambrosini G, Adida C, Altieri DC: A novel anti-apoptosis gene, survivin, expressed in cancer and lymphoma. Nat Med 1997, 3:917-921.

194. Li F, Ackermann EJ, Bennett CF, Rothermel AL, Plescia J, Tognin S, Villa A, Marchisio PC, Altieri DC: Pleiotropic cell-division defects and apoptosis induced by interference with survivin function. Nat Cell Biol 1999, 1:461-466.

195. Li F, Ambrosini G, Chu EY, Plescia J, Tognin S, Marchisio PC, Altieri DC: Control of apoptosis and mitotic spindle checkpoint by survivin. Nature 1998, 396:580-584.

196. Fukuda S, Pelus LM: Elevation of Survivin levels by hematopoietic growth factors occurs in quiescent CD34+ hematopoietic stem and progenitor cells before cell cycle entry. Cell Cycle 2002, 1:322-326.

197. Fukuda S, Foster RG, Porter SB, Pelus LM: The antiapoptosis protein survivin is associated with cell cycle entry of normal cord blood CD34(+) cells and modulates cell cycle and proliferation of mouse hematopoietic progenitor cells. Blood 2002, 100:2463-2471.

198. Fukuda S, Mantel CR, Pelus LM: Survivin regulates hematopoietic progenitor cell proliferation through p21WAF1/Cip1-dependent and -independent pathways. Blood 2004, 103:120-127.

199. Leung CG, Xu Y, Mularski B, Liu H, Gurbuxani S, Crispino JD: Requirements for survivin in terminal differentiation of erythroid cells and 
maintenance of hematopoietic stem and progenitor cells. J Exp Med 2007, 204:1603-1611.

200. Kikuchi H, Ohtsuka E, Ono K, Nakayama T, Saburi Y, Tezono K, Ogata M, Iwahashi M, Nasu M: Allogeneic bone marrow transplantation-related transmission of human T lymphotropic virus type I (HTLV-I). Bone Marrow Transplant 2000, 26:1235-1237.

201. Matsuoka M, Green PL: The HBZ gene, a key player in HTLV-1 pathogenesis. Retrovirology 2009, 6:71.

202. Usui T, Yanagihara K, Tsukasaki K, Murata K, Hasegawa H, Yamada Y, Kamihira S: Characteristic expression of HTLV-1 basic zipper factor (HBZ) transcripts in HTLV-1 provirus-positive cells. Retrovirology 2008, 5:34.

203. Tamiya S, Matsuoka M, Etoh K, Watanabe T, Kamihira S, Yamaguchi K, Takatsuki K: Two types of defective human T-lymphotropic virus type I provirus in adult T-cell leukemia. Blood 1996, 88:3065-3073.

doi:10.1186/1742-4690-7-8

Cite this article as: Banerjee et al: Hematopoietic stem cells and retroviral infection. Retrovirology 2010 7:8.

\section{Submit your next manuscript to BioMed Central} and take full advantage of:

- Convenient online submission

- Thorough peer review

- No space constraints or color figure charges

- Immediate publication on acceptance

- Inclusion in PubMed, CAS, Scopus and Google Scholar

- Research which is freely available for redistribution

Submit your manuscript at www.biomedcentral.com/submit 